\title{
Climate variability and ocean fertility during the Aptian Stage
}

\author{
C. Bottini ${ }^{1}$, E. Erba ${ }^{1}$, D. Tiraboschi ${ }^{1}$, H. C. Jenkyns ${ }^{2}$, S. Schouten ${ }^{3}$, and J. S. Sinninghe Damsté ${ }^{3}$ \\ ${ }^{1}$ Department of Earth Sciences, Università degli Studi di Milano, 20133 Milan, Italy \\ ${ }^{2}$ Department of Earth Sciences, University of Oxford, South Parks Road, Oxford OX1 3AN, UK \\ ${ }^{3}$ NIOZ Royal Netherlands Institute for Sea Research, Department of Marine Organic Biogeochemistry, \\ P.O. Box 59, 1790 AB Den Burg Texel, the Netherlands
}

Correspondence to: C. Bottini (cinzia.bottini@unimi.it)

Received: 28 January 2014 - Published in Clim. Past Discuss.: 21 February 2014

Revised: 26 November 2014 - Accepted: 10 January 2015 - Published: 5 March 2015

\begin{abstract}
Several studies have been conducted to reconstruct temperature variations across the Aptian Stage, particularly during early Aptian Oceanic Anoxic Event (OAE) 1a. There is a general consensus that a major warming characterized OAE 1a, although some studies have provided evidence for transient "cold snaps" or cooler intervals during the event. The climatic conditions for the middle-late Aptian are less constrained, and a complete record through the Aptian is not available. Here we present a reconstruction of surface-water palaeotemperature and fertility based on calcareous nannofossil records from the Cismon and Piobbico cores (Tethys) and DSDP Site 463 (Pacific Ocean). The data, integrated with oxygen-isotope and $\mathrm{TEX}_{86}$ records, provide a detailed picture of climatic and ocean fertility changes during the Aptian Stage, which are discussed in relation to the direct/indirect role of volcanism. Warm temperatures characterized the pre-OAE 1a interval, followed by a maximum warming (of $\sim 1.5-2{ }^{\circ} \mathrm{C}$ ) during the early phase of anoxia under intense volcanic activity of the Ontong Java Plateau (OJP). A short-lived cooling episode interrupted the major warming, following a rapid increase in weathering rates. Nannofossils indicate that mesotrophic conditions were reached when temperatures were at their highest and OJP volcanism most intense, thus suggesting that continental runoff, together with increased input of hydrothermal metals, increased nutrient supply to the oceans. The latter part of OAE 1a was characterized by cooling events, probably promoted by $\mathrm{CO}_{2}$ sequestration during burial of organic matter. In this phase, high productivity was probably maintained by $\mathrm{N}_{2}$-fixing cyanobacteria, while nannofossil taxa indicating higher fertility were rare. The end of anoxia coincided with the cessation of volcanism and a pronounced cooling.
\end{abstract}

The mid-Aptian was characterized by highest surface-water fertility and progressively decreasing temperatures, probably resulting from intense continental weathering drawing down $p \mathrm{CO}_{2}$. The lowest temperatures, combined with low fertility, were reached in the middle-late Aptian across the interval characterized by blooming of Nannoconus truittii. The prolonged cooling was followed by significant warming across the Aptian-Albian boundary. The data presented suggest that OJP activity played a direct role in inducing global warming during the early Aptian, whereas other mechanisms (weathering, deposition of organic matter) acted as feedback processes, favouring temporary cooler interludes.

\section{Introduction}

The Aptian $(\sim 121$ to $\sim 113 \mathrm{Ma}$; Malinverno et al., 2012$)$ has been characterized by climatic changes and profound environmental perturbations including Oceanic Anoxic Event 1a (OAE 1a: 120 Ma), representing a global phenomenon of organic-matter burial in oxygen-depleted oceans. The disturbance in the carbon cycle related to OAE $1 \mathrm{a}$ is recorded in sedimentary successions worldwide, presenting a negative carbon-isotope anomaly at the onset of OAE $1 \mathrm{a}$, followed by a positive excursion that extends into the late Aptian (e.g. Weissert, 1989; Weissert and Lini, 1991; Jenkyns, 1995; Menegatti et al., 1998; Bralower et al., 1999; Erba et al., 1999; Luciani et al., 2001; Bellanca et al., 2002; Price, 2003; van Breugel et al., 2007; Ando et al., 2008; Méhay et al., 2009; Malkoč et al., 2010; Mahanipour et al., 2011; Millán et al., 2009; Stein et al., 2011; Bottini et al., 2012; Hu et al., 2012). Volcanism, associated with the emplacement 
of the Ontong Java Plateau (OJP), is thought to be the main triggering mechanism for global anoxia as well as for imposed greenhouse conditions (e.g. Larson, 1991; Erba, 1994; Bralower et al., 1994; Larson and Erba, 1999; Jones and Jenkyns, 2001; Leckie et al., 2002; Jenkyns, 2003; Méhay et al., 2009; Tejada et al., 2009; Bottini et al., 2012) and ocean acidification (Erba et al., 2010) during OAE 1a.

Several studies are suggestive of significant temperature increase during OAE 1a, as recorded by different temperature proxies (i.e. oxygen isotopes, $\mathrm{TEX}_{86}$, calcareous nannofossils, palynomorphs) in the Tethys (e.g. Menegatti et al., 1998; Hochuli et al., 1999; Luciani et al., 2001; Bellanca et al., 2002; Jenkyns, 2003, 2010; Millán et al., 2009; Erba et al., 2010; Keller et al., 2011; Stein et al., 2011; Bottini et al., 2012; Hu et al., 2012; Husinec et al., 2012), Vocontian Basin (e.g. Moullade et al., 1998; Kuhnt et al., 2011), Lower Saxony Basin (Mutterlose et al., 2010, 2014; Bottini and Mutterlose, 2012; Pauly et al., 2013), North Sea (Mutterlose and Bottini, 2013), Russian Platform (Zakharov et al., 2013), Pacific (e.g. Jenkyns, 1995; Price, 2003; Schouten et al., 2003; Ando et al., 2008; Bottini et al., 2012) and Atlantic oceans (e.g. Tremolada et al., 2006). Some works have provided evidence for climatic variability during OAE 1a, identifying short-lived cooling events (e.g. Dumitrescu et al., 2006; Keller et al., 2011; Kuhnt et al., 2011; Jenkyns et al., 2012; Lorenzen et al., 2013). At the end of OAE 1a, a temperature decline is registered in the Tethys (e.g. Weissert and Lini, 1991; Menegatti et al., 1998; Hochuli et al., 1999; Luciani et al., 2001; Bellanca et al., 2002; Millán et al., 2009), Vocontian Basin (e.g. Herrle et al., 2010; Kuhnt et al., 2011), Boreal Realm (e.g. Rückheim et al., 2006; Malkoč et al., 2010; Bottini and Mutterlose, 2012; Pauly et al., 2013; Mutterlose and Bottini, 2013) and Pacific Ocean (e.g. Jenkyns, 1995; Jenkyns and Wilson, 1999; Price, 2003; Dumitrescu et al., 2006; Ando et al., 2008).

For the late Aptian, cooler conditions have been reconstructed based on migration of boreal species southwards (e.g. Herrle and Mutterlose, 2003; Mutterlose et al., 2009), oxygen-isotope records (e.g. Weissert and Lini, 1991; Jenkyns, 1995; Hu et al., 2012; Price et al., 2012; Maurer et al., 2012; Peybernès et al., 2013), putative ice-rafted debris in high latitudes (Kemper, 1987; Frakes and Francis, 1988; De Lurio and Frakes, 1999; Price, 1999) and, for seabottom temperatures, the presence of glendonites (marine low-temperature hydrated polymorphs of calcium carbonate) (Kemper, 1987). Recently McAnena et al. (2013) have documented, on the basis of $\mathrm{TEX}_{86}$ data, a $\sim 2 \mathrm{Myr}$ long interval of relatively cool conditions $\left(\sim 28-29^{\circ} \mathrm{C}\right)$ in the late Aptian in the proto-North Atlantic followed by a warming (up to $\sim 31^{\circ} \mathrm{C}$ ), linked to OAE $1 \mathrm{~b}$.

Although the amount of information about temperature variations across the Aptian is considerable, a complete picture of climatic changes is not available. In most cases, the records are poorly correlated between the different basins and/or cover limited time intervals within the $\sim 12 \mathrm{Myr}$ long
Aptian Stage (Malinverno et al., 2012). In this work, we focus primarily on surface-water temperatures through the Aptian reconstructed on the basis of calcareous nannofossils from three well sites: Cismon (Italian Southern Alps), Piobbico (Umbria-Marche Basin, central Italy) and DSDP Site 463 (Mid-Pacific Mountains). The existing stratigraphic framework for the three sites and available cyclochronology for the Cismon core (Malinverno et al., 2010) allow for high-resolution dating of climatic fluctuations. Calcareous nannoplankton live in the (upper) photic zone and are a good proxy of present and past surface-water conditions, being sensitive to temperature, fertility, salinity and $p \mathrm{CO}_{2}$ (Mutterlose et al., 2005). Extant calcareous nannoplankton occur from coastal areas to the open ocean, although with different abundance and diversity and, together with diatoms, dinoflagellates and bacteria constitute marine phytoplanktonic communities. The Mesozoic geological record confirms the wide geographical/latitudinal distribution of calcareous nannofossils (coccoliths and nannoliths) that are commonly used to trace palaeoecological conditions. Within nannofossil assemblages, nannoconids are inferred to have been restricted to the deep photic zone at the base of the mixed layer on top of the thermocline coinciding with a deep nutricline (Erba, 1994). In the studied intervals, nannoconids are relatively scarce, and micrite mostly consists of coccoliths, thus essentially recording the uppermost water masses.

In this work, stable oxygen isotopes on bulk rock have been measured to reconstruct changes in surface-water temperature, taking into account potential diagenetic modification. The preservation of nannofossils provides information on the early diagenetic history of pelagic carbonates (Erba, 1992b; Herrle et al., 2003; Tiraboschi et al., 2009). Although oxygen-isotope ratios contain a mixture of a primary signal and later diagenetic phases (Marshall, 1992), hampering the use of palaeotemperature values, the $\delta^{18} \mathrm{O}$ bulk data can be used to derive trends toward warmer/cooler conditions. New oxygen-isotope data for DSDP Site 463 and Piobbico have been generated, and these are directly correlated with calcareous nannofossil variations as well as with new $\mathrm{TEX}_{86}$ data from the Cismon core.

The aims of our work are to (a) trace climatic variations during the Aptian Stage; (b) reconstruct, in high resolution, the climate variability through OAE 1a; (c) identify synchroneity and diachroneity of temperature variations in different oceanic basins; and (d) trace the direct/indirect role of volcanism, weathering rates and $p \mathrm{CO}_{2}$ on climate changes connected with OAE $1 \mathrm{a}$ and its aftermath.

We also characterize the evolution of surface-water fertility during the Aptian Stage. Previous studies (e.g. Coccioni et al., 1992; Bralower et al., 1993; Erba, 1994, 2004; Premoli Silva et al., 1999; Leckie et al., 2002; Mutterlose et al., 2005; Tremolada et al., 2006; Bottini and Mutterlose, 2012) mainly focused on the OAE 1a interval, documenting an increase in surface-water fertility accompanied by high primary productivity, but a record throughout the entire Aptian is missing. 
We therefore highlight fluctuations in fertility before, during and after OAE $1 \mathrm{a}$, identifying potential relationships with climatic changes in both the short and the long term as well as oceanic nutrification.

\section{Material and methods}

\subsection{Studied sites}

We have investigated the Upper Barremian-Aptian interval at three sites in the Tethys and Pacific oceans (Fig. 1):

The Cismon core, drilled in the Italian Southern Alps, north-eastern Italy $\left(46^{\circ} 02^{\prime} \mathrm{N}, 11^{\circ} 45^{\prime} \mathrm{E} ; 398 \mathrm{~m}\right.$ altitude), is represented by a total stratigraphic thickness of $131.8 \mathrm{~m}$ with $100 \%$ recovery. The site was located on the southern margin of the Mesozoic Tethys, on the eastward deepening slope between the Trento Plateau (a pelagic submarine high) and the Belluno Basin (Erba and Tremolada, 2004). The Cismon sequence was deposited at an estimated palaeo-depth of 1000-1500 m during the Early Cretaceous (Weissert and Lini, 1991; Erba and Larson, 1998; Bernoulli and Jenkyns, 2009). In the uppermost part of the cored section (at $7.80 \mathrm{~m}$ ) there is a major hiatus corresponding to the late Aptian and the early-middle Albian. The Selli Level (sedimentary expression of OAE 1a) is represented by a $\sim 5 \mathrm{~m}$ thick interval, between 23.67 and 18.64 stratigraphic metre depths (Erba and Larson, 1998; Erba et al., 1999). Lithologically, the Selli Level is characterized by marlstones alternating with black shales and discrete radiolarian-rich beds (Coccioni et al., 1987; Erba et al., 1999). The interval studied extends from 35 to $10 \mathrm{~m}$.

The Piobbico core was drilled at "Le Brecce" $\left(43^{\circ} 35^{\prime} 3.78^{\prime \prime} \mathrm{N} ; 12^{\circ} 29^{\prime} 10.09^{\prime \prime} \mathrm{E}\right)$, located $3 \mathrm{~km}$ west of the town of Piobbico (Marche, Italy), at $\mathrm{Km} 33$ of Apecchiese State Road No. 257, on the left hydrographic side of the Biscubio stream. The Piobbico site was located at an estimated palaeo-depth of $\sim 1500 \mathrm{~m}$ during the Cretaceous. Coring penetrated the entire Marne a Fucoidi Formation, including the upper transition to the Scaglia Bianca and the lower transition to the Maiolica. The total length of the core is $84 \mathrm{~m}$ with $98.8 \%$ recovery; after adjusting for dip direction, the stratigraphic thickness equals $77 \mathrm{~m}$. The lithostratigraphy and calcareous plankton biostratigraphy of the core were described by Erba $(1988,1992 a)$ and Tornaghi et al. (1989). The Selli Level, consisting of black shales and radiolarian-rich beds, extends from 75.94 to $73.47 \mathrm{~m}$. The interval studied covers the interval from 77 to $40 \mathrm{~m}$.

DSDP Site 463 was drilled at a water depth of $2525 \mathrm{~m}$ on the ancient structural high of the western Mid-Pacific Mountains $\left(21^{\circ} 21.01^{\prime} \mathrm{N}, 174^{\circ} 40.07^{\prime} \mathrm{E}\right)$ during DSDP Leg 62. During the Early Cretaceous, Site 463 was located at a palaeolatitude of $\sim 20^{\circ} \mathrm{S}$, with a palaeo-depth between a few hundred metres (Mélières et al., 1978) and $\sim 1 \mathrm{~km}$ (Roth, 1981). The Selli Level equivalent is located between $\sim 626$ and $615 \mathrm{mbsf}$, corresponding to $\sim 12 \mathrm{~m}$ of tuffaceous limestones containing a number of discrete organic-rich horizons (Thiede et al., 1981; Erba, 1994). The interval studied covers a depth range from 650 to $515 \mathrm{mbsf}$.

\subsection{Calcareous nannofossils}

Calcareous nannofossil assemblages were quantitatively investigated under polarizing light microscope at $1250 \times$ magnification in smear slides prepared using standard techniques, without centrifuging or cleaning in order to retain the original sedimentary composition. A small quantity of rock was powdered in a mortar with bi-distillate water and mounted on a glass slide with Norland optical adhesive. A total of 285 smear slides for the Cismon core, 179 smear slides for the Piobbico core and 281 smear slides for DSDP Site 463 were investigated. At least 300 nannofossil specimens were counted in each sample and percentages of single taxa were calculated relative to the total nannoflora.

Previous investigations of Aptian nannofossil assemblages in the Piobbico core, Cismon core and DSDP Site 463 focused on relative abundances of nannoconids, nannoliths and a few selected coccolith taxa (Erba, 1994; Premoli Silva et al., 1999; Erba and Tremolada, 2004; Erba et al., 2010) across OAE 1a. Here, we extend quantitative investigation of nannofossil assemblages in smear slides to all taxa in the latest Barremian-Aptian time interval.

Quantitative investigation of nannoconid abundance was performed on a total of 161 thin sections for the Cismon core (85 new thin sections integrating the data set of Erba and Tremolada, 2004, and Erba et al., 2010), 221 for DSDP Site 463 (101 new thin sections integrating the data set of Erba et al., 2010) and 179 for Piobbico. Thin sections were polished to an average thickness of $7 \mu \mathrm{m}$ for an optimal view of nannofossils. Absolute abundances were obtained by counting all nannoconids in $1 \mathrm{~mm}^{2}$ of the thin section.

\subsection{Oxygen-isotope analysis}

New oxygen stable-isotope analyses were performed at Oxford University on bulk carbonate fraction of 57 samples from DSDP Site 463 and of 373 samples from Piobbico. Bulk-rock samples for isotopic analysis were first powdered and cleaned with $10 \% \mathrm{H}_{2} \mathrm{O}_{2}$, followed by acetone, and then dried at $60^{\circ} \mathrm{C}$. Powders were then reacted with purified orthophosphoric acid at $90^{\circ} \mathrm{C}$ and analysed online using a VG Isocarb device and Prism mass spectrometer. Long-term reproducibility, as determined from repeat measurements of the in-house standard (Carrara marble), resulted in analytical uncertainties of $\delta^{18} \mathrm{O}=-1.86 \pm 0.1$. The values are reported in the conventional delta notation with respect to the Vienna Pee Dee Belemnite (V-PDB) standard. For DSDP Site 463, data are drawn from Price (2003), Ando et al. (2008) and this work, and for the Cismon core $\delta^{18} \mathrm{O}$ come from Méhay et al. (2009) and Erba et al. (2010). 


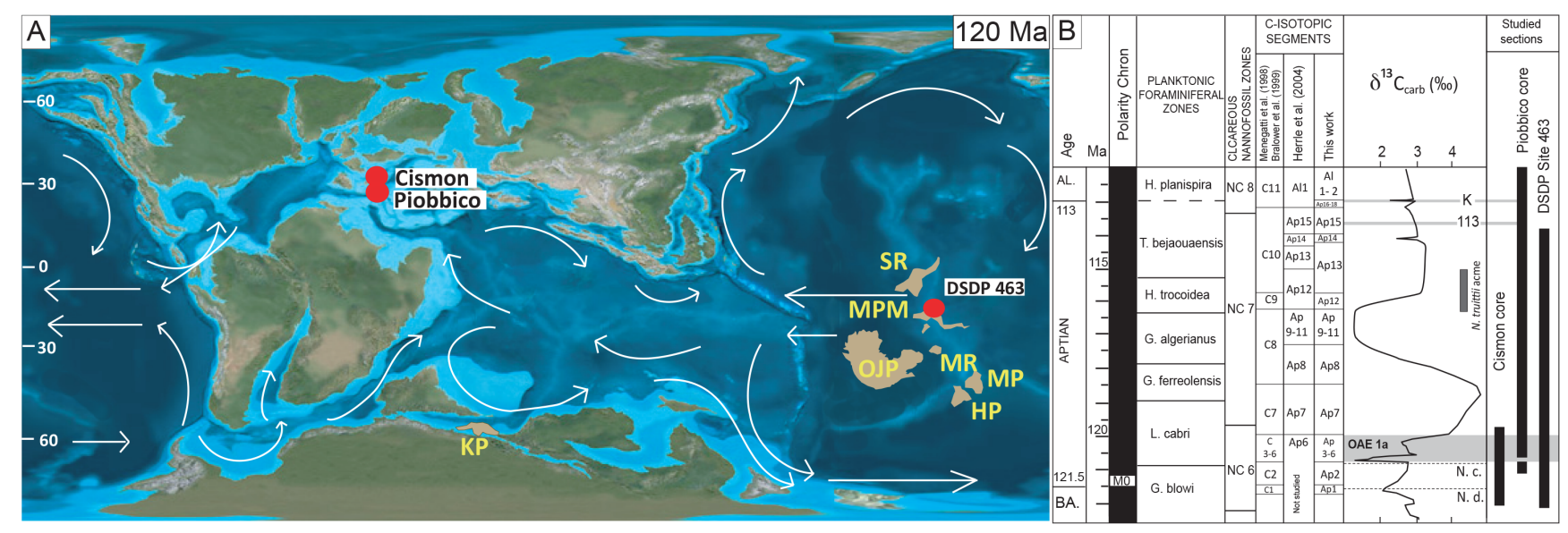

Figure 1. (a) Location map of studied sites at $120 \mathrm{Ma}$ (modified after Erba et al., 2015). OJP: Ontong Java Plateau; KP: Kerguelen Plateau; SR: Shatsky Rise; MPM: Mid-Pacific Mountains; MR: Magellan Rise; MP: Manihiki Plateau; HP: Hikurangi Plateau. (b) Stratigraphic ranges of the studied sections. Latest Barremian to earliest Albian chronologic framework is from Erba et al. (2015). Numerical ages are based on the timescale of Malinverno et al. (2012). Codes for C-isotope segments after Menegatti et al. (1998), Bralower et al. (1999), Herrle et al. (2004) and this work are reported. K: Niveau Kilian; 113: 113 Level; N.c.: Nannoconid crisis; N.d.: Nannoconid decline.

\section{$2.4 \quad$ TEX $_{86}$}

Sediments from the Cismon core were extracted as described by van Breugel et al. (2007). The polar fractions of the extracts, containing the glycerol dialkyl glycerol tetraether (GDGT) lipids, were dried under a stream of nitrogen $\left(\mathrm{N}_{2}\right)$, redissolved by sonication ( $5 \mathrm{~min}$ ) in $200 \mu \mathrm{L}$ hexane/propanol (99: 1, vol : vol) and filtered through $0.45 \mu \mathrm{m}$ polytetrafluoroethylene (PTFE) filters. GDGTs were analysed by means of high-pressure liquid chromatography-mass spectrometry (HPLC/MS) following the method described by Schouten et al. (2007). Samples were analysed on an Agilent 1100 series LC/MSD SL. A Prevail Cyano column $(150 \mathrm{~mm} \times 2.1 \mathrm{~mm}$, $3 \mathrm{~mm}$ ) was used with hexane : propanol $(99: 1$, vol : vol) as an eluent. After the first $5 \mathrm{~min}$, the eluent increased by a linear gradient up to $1.8 \%$ isopropanol (vol) over the next $45 \mathrm{~min}$ at a flow rate of $0.2 \mathrm{~mL} \mathrm{~min}^{-1}$. Identification and quantification of the GDGTs isomers was achieved by integrating the peak areas of relevant peaks in $\mathrm{m} / z$ 1300, 1298, 1296, 1292, 1050, 1036 and 1022 selected ion monitoring scans. The TEX 86 ratio was calculated following Schouten et al. (2002):

$$
\begin{aligned}
\text { TEX }_{86} & =([\text { GDGT } 2]+[\text { GDGT 3 }] \\
& +[\text { crenarchaeol regioisomer }]) /([\text { GDGT 1 }] \\
& +[\text { GDGT } 2]+[\text { GDGT } 3] \\
& +[\text { crenarchaeol regioisomer }])
\end{aligned}
$$

where numbers correspond to isoprenoid GDGTs from marine Thaumarchaeota with 1, 2 or 3 cyclopentane moieties, and the crenarchaeol regioisomer has the antiparallel configuration of crenarchaeol (Sinninghe Damsté et al., 2002).

The TEX 86 values were converted to SST using the most recent calibration as proposed by Kim et al. (2010) for oceans with $\mathrm{SST}>15^{\circ} \mathrm{C}$ :

$\mathrm{SST}=38.6+68.4 \cdot \log \left(\mathrm{TEX}_{86}\right)$.

The branched and isoprenoid tetraether (BIT) index is based on the relative abundance of non-isoprenoidal GDGTs derived from soil bacteria versus a structurally related isoprenoid GDGT, "crenarchaeol", with four cyclopentane moieties and one cyclohexane moiety, produced by marine Thaumarchaeota. The BIT index, which thus represents a measure for soil versus marine organic matter input in marine sediments, was calculated according to Hopmans et al. (2004):

$$
\begin{aligned}
\mathrm{BIT} & =([\text { GDGT-I }]+[\text { GDGT-II }] \\
& +[\text { GDGT-III }]) /([\text { crenarchaeol }]+[\text { GDGT-I }] \\
& +[\text { GDGT-II }]+[\text { GDGT-III }]) .
\end{aligned}
$$

\section{Stratigraphic framework}

In this work, the stratigraphic framework for the three cores investigated is based on carbon-isotope stratigraphy calibrated with calcareous nannofossil and foraminiferal biostratigraphy. For the Cismon core and DSDP Site 463, magnetic chron CM0 has been used to define the base of the Aptian; this level was not reached with the Piobbico core.

In addition to the two well-known, high-amplitude $\delta^{13} \mathrm{C}$ Aptian excursions, several minor fluctuations are identified in the carbon-isotope record from the Tethys, Pacific and Atlantic oceans, which allow codification of major and minor perturbations. Menegatti et al. (1998) focused on the late Barremian-early Aptian interval and identified segments C1-C8. Subsequently, Bralower et al. (1999) extended the codification of Menegatti et al. (1998) through the rest of 
the Aptian Stage (C1-C11). Herrle et al. (2004) introduced new codes for the Aptian starting from Ap6, coinciding with C5 and C6 of Menegatti et al. (1998), to Al2. McAnena et al. (2013) used the Ap9-Al3 segments previously identified by Herrle et al. (2004).

The studied sections cover the latest Barremian-earliest Albian time interval. We revised the Herrle et al. (2004) carbon-isotope segments by extending their codes down to Ap1 and renaming the earliest Albian fluctuations Al1-Al3 (Fig. 1). Segments Ap1-Ap7 coincide with previously identified segments C1-C7 (Menegatti et al., 1998). The $\delta^{13} \mathrm{C}$ curve for the rest of the Aptian shows several fluctuations, allowing a higher resolution subdivision into segments Ap8Ap18. In this paper, we applied a double coding for Ap1/C1 through Ap7/C7 segments (Figs. 1 and 2) and used the new Ap8-Ap18 and Al1-Al3 codes for the late Aptian-earliest Albian time interval. We identify segments Ap1-Ap8 at Cismon, Ap2-A13 at Piobbico and Ap1-Ap15 at DSDP Site 463 (Figs. 1, 3, 4 and 5). Segments Ap8-Ap15 are less well defined at DSDP Site 463 due to incomplete core recovery.

In addition to nannofossil zones NC6-NC8 (Bralower et al., 1995), we used the "nannoconid decline" and the "nannoconid crisis" (e.g. Erba et al., 2010) as further bio-horizons. Moreover, in the late Aptian the "Nannoconus truittii acme" (Mutterlose, 1989; Erba, 1994; Herrle and Mutterlose, 2003) defines a globally recognized interval where $N$. truittii dominates the assemblages with relative abundances from 5 to $40 \%$ of the total nannofloras.

As far as lithostratigraphy is concerned, the Selli Level or its equivalents are identified at all three sites. A lithological revision of the Piobbico core also allowed the identification of the Kilian Level Equivalent, corresponding to the prominent black shale at the bottom of lithological Unit 12 within core 44 (Erba, 1988). The Kilian Level Equivalent in the Piobbico core is characterized by very fine laminations, without bioturbation, and has a thickness of $33 \mathrm{~cm}$ (from 45.13 to $44.80 \mathrm{~m}$ ). Following Petrizzo et al. (2012), the Kilian Level marks the Aptian-Albian boundary.

Regarding the Piobbico core, we identify the presence of a hiatus that eliminates part of the basal Selli Level. In particular, on the basis of the correlation between the lithology and carbon-isotope record from the Piobbico core with the equivalent records from the Cismon core and DSDP Site 463 (Fig. 2), as well as from other sedimentary basins, we note that (1) the $\delta^{13} \mathrm{C}$ values from 75.94 to $74.80 \mathrm{~m}$, ranging between 2 and $3 \%$, probably correspond to segments Ap4/C4 and Ap5/C5 rather than to the negative excursion Ap3/C3 where values of Cismon and DSDP Site 463 sediments are below $1 \%$; (2) $\delta^{18} \mathrm{O}$ values from 75.94 to $74.80 \mathrm{~m}$ fall between -3 and $-1 \%$ and never reach the highly negative values $(-4 \%$ o) characteristic of those in the Ap3/C3 segment of the other two sites, but rather conform to the range of values detected in segments Ap4/C4 and Ap5/C5; and (3) the Selli Level in the Cismon core is characterized by three lithological sub-units (Erba et al., 1999), the lowermost being represented by laminated black shales corresponding to segment $\mathrm{Ap} 3 / \mathrm{C} 3$, the second characterized by prevailing light grey marlstones corresponding to segments Ap4/C4 and Ap5/C5, and the uppermost one characterized by laminated black shales corresponding to segment Ap6/C6. The total organic carbon content (TOC) in the Cismon core shows highest values corresponding to segments Ap4/C4, the base of segment Ap5/C5, as well as segment Ap6/C6. Similarly high values are detected at DSDP Site 463 in coeval stratigraphic positions. At Piobbico, only two lithological sub-units are recognized (Erba, 1988) following the definition of Coccioni et al. (1987, 1989). The lower part, namely the "green interval", is dominated by light-green claystones, while the upper "black interval" is characterized by laminated black shales. It is therefore possible that the lowermost black shale interval normally found in the Selli Level equivalents is missing at Piobbico and only the other two lithostratigraphic intervals, corresponding to Ap4/C4-Ap5/C5 and Ap6/C6, respectively, are represented.

\section{Results}

\subsection{Calcareous nannofossil abundances}

Calcareous nannofossils are generally common to abundant in the studied sections and characterized by moderate preservation, with negligible evidence of recrystallization in limestones and dissolution in black shales. Only a few samples in the lower part of the Selli Level are barren, possibly due to dissolution. The detected abundance fluctuations of dissolution-resistant and dissolution-prone taxa indicate that diagenesis cannot be responsible for changes that are similar and synchronous in different oceans. Moreover, changes in abundances occur in lithologies yielding identical preservation. Specifically, nannoconids are most resistant to dissolution/diagenesis, and their decline, crisis and acme are proved to be independent from preservation (Erba, 1994; Erba et al., 2010). In addition, as pointed out by Erba et al. (2011), the abundance of delicate and dissolution-prone species (e.g. Biscutum constans, Zeugrhabdotus erectus, Discorhabdus rotatorius) is opposite to what diagenesis would produce.

In all the three sections investigated, samples are characterized by relatively high percentages of Watznaueria barnesiae (Figs. 3, 4 and 5). This taxon is considered a dissolutionresistant species, and assemblages containing more than $40 \%$ are thought to be heavily altered (e.g. Thierstein and Roth, 1991). However, percentages higher than $40 \%$ of $W$. barnesiae may preserve a primary signal in oceanic settings, and/or in oligotrophic conditions (Roth and Krumbach, 1986; Erba et al., 1992; Williams and Bralower, 1995; Herrle et al., 2003a; Mutterlose et al., 2005). We believe that the relatively high percentages of $W$. barnesiae in the studied sections preserve a primary signal. 


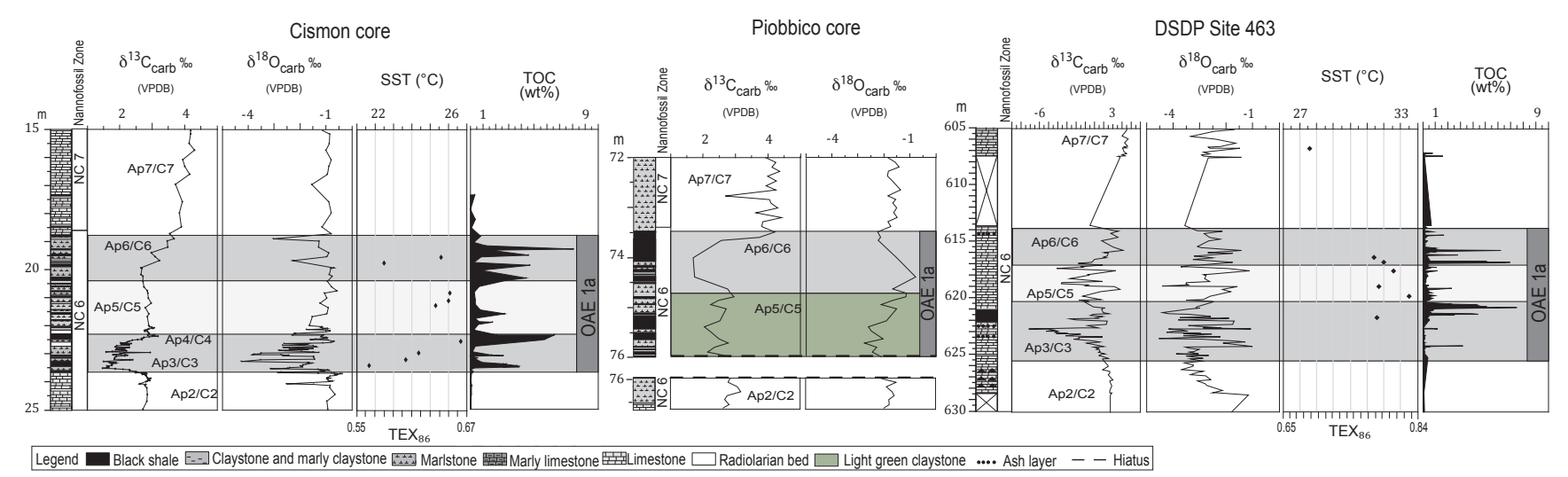

Figure 2. Correlation between the Cismon core, the Piobbico core and DSDP Site 463. $\delta^{13} \mathrm{C}$ data after Erba et al. (1999) and Méhay et al. (2009) for the Cismon core; Erba et al. (2015) for the Piobbico core; Price (2003), Ando et al. (2008) and Bottini et al. (2012) for DSDP Site 463. Bulk $\delta^{18} \mathrm{O}$ data after Erba et al. (2010) for the Cismon core; Price (2003), Ando et al. (2008) and this work for DSDP Site 463. TOC after Erba et al. (1999) and Bottini et al. (2012) for the Cismon core; Ando et al. (2008) for DSDP Site 463 . TEX 86 after Schouten et al. (2003) for DSDP Site 463; this work for the Cismon core. For both cores SST was calculated using the equation of Kim et al. (2010). Grey bands indicate intervals of higher TOC values.

Mutterlose et al. (2005) reviewed the palaeoecological affinities of some mid-Cretaceous taxa synthesizing major studies that allowed the identification of species related to palaeofertility and palaeotemperatures of surface waters. Figures 3-5 illustrate the distribution of the higher-fertility (D. rotatorius, B. constans, $Z$. erectus) and lower-fertility (W. barnesiae) nannofossil taxa (following Roth and Krumbach, 1986; Premoli Silva et al., 1989a, b; Watkins, 1989; Coccioni et al., 1992; Erba et al., 1992b; Williams and Bralower, 1995; Bellanca et al., 1996; Herrle, 2003; Herrle et al., 2003a; Bornemann et al., 2005; Mutterlose et al., 2005; Tremolada et al., 2006; Tiraboschi et al., 2009), as well as of the warm-temperature (Rhagodiscus asper, Zeugrhabdotus diplogrammus) and cool-temperature (Staurolithites stradneri, Eprolithus floralis, Repagulum parvidentatum) taxa (following Roth and Krumbach, 1986; Bralower, 1988; Wise Jr., 1988; Erba, 1992b; Erba et al., 1992; Mutterlose, 1992; Herrle and Mutterlose, 2003; Herrle et al., 2003a; Tiraboschi et al., 2009).

A description of the major trends of these taxa is given for the three sections investigated:

In the Cismon core (Fig. 3), W. barnesiae is the dominant species with mean abundance of $66.8 \%$. Rhagodiscus asper ranges from 0 to $20 \%$ of the total assemblage (mean: $3 \%$ ), showing the highest peaks in the lowermost part of the Selli Level (segments Ap3/C3 and Ap4/C4 of the carbonisotope curve). Zeugrhabdotus diplogrammus ranges from 0 to $2 \%$ (mean: $0.1 \%$ ). Staurolithites stradneri ranges from 0 to $4 \%$ (mean: $0.2 \%$ ), and shows peaks in the uppermost part of the Selli Level (segment Ap6/C6). Eprolithus floralis ranges from 0 to $6 \%$ (mean: $0.2 \%$ ) and shows peaks just above the top of the Selli Level (Ap7/C7). Biscutum constans ranges from 0 to $2 \%$ (mean: $0.2 \%$ ), D. rotatorius from 0 to $3.5 \%$ (mean: $0.4 \%$ ) and $Z$. erectus from 0 to $4.1 \%$ (mean:
$0.15 \%)$. These three species are more abundant in the lower part of the Selli Level (segments Ap3/C3, Ap4/C4 and part of Ap5/C5). Nannoconids show a decline in abundance starting prior to magnetic chron CM0 (where they show high abundances up to $40 \%$ in smear slides; $1 \times 10^{4}$ specimens $\mathrm{mm}^{-2}$ in thin section) and reaching a minimum corresponding to segment Ap3/C3 of the carbon-isotope curve, where they are virtually absent.

In the Piobbico core (Fig. 4), the interval from 75.29 to $73.92 \mathrm{~m}$, within the Selli Level, is barren of calcareous nannofossils. In the rest of studied interval, $W$. barnesiae is the dominant species with a mean abundance of $62 \%$. Rhagodiscus asper ranges from 0 to $7.7 \%$ (mean: $2.4 \%$ ). Zeugrhabdotus diplogrammus fluctuates between 0 and $1.2 \%$ (mean: $1 \%$ ). Eprolithus floralis ranges from 0 to $3.5 \%$ (mean: $0.5 \%$ ), $R$. parvidentatum from 0 to $0.3 \%$ (mean: $0.04 \%$ ) and S. stradneri from 0 to $3 \%$ (mean: $0.6 \%$ ); these taxa are more abundant above the Selli Level, showing the highest values in correspondence to segments Ap11 and Ap13Ap15 of the carbon-isotope curve. Biscutum constans ranges from 0 to $4.1 \%$ (mean: $0.1 \%$ ), D. rotatorius from 0 to $20 \%$ (mean: $2.7 \%$ ) and Z. erectus from 0 to $6.5 \%$ (mean: $0.9 \%$ ). The latter three species are more abundant corresponding to segments Ap9-Ap11 of the carbon-isotope curve. Nannoconids are absent to rare throughout most of the studied interval except for an interval between 60.37 and $55.61 \mathrm{~m}$, where they show rather high abundances (up to $40 \%$ relative abundance in smear slides; $4 \times 10^{3}$ specimens $\mathrm{mm}^{-2}$ absolute abundance in thin section). This particular interval is dominated by $N$. truittii and coincides with the " $N$. truittii acme".

At DSDP Site 463 (Fig. 5), the intervals from 624.24 to $623.96 \mathrm{mbsf}$ and from 623.16 to $622.57 \mathrm{mbsf}$, within the Selli Level, are barren of calcareous nannofossils. Watznaueria barnesiae is the dominant species with a mean abundance 


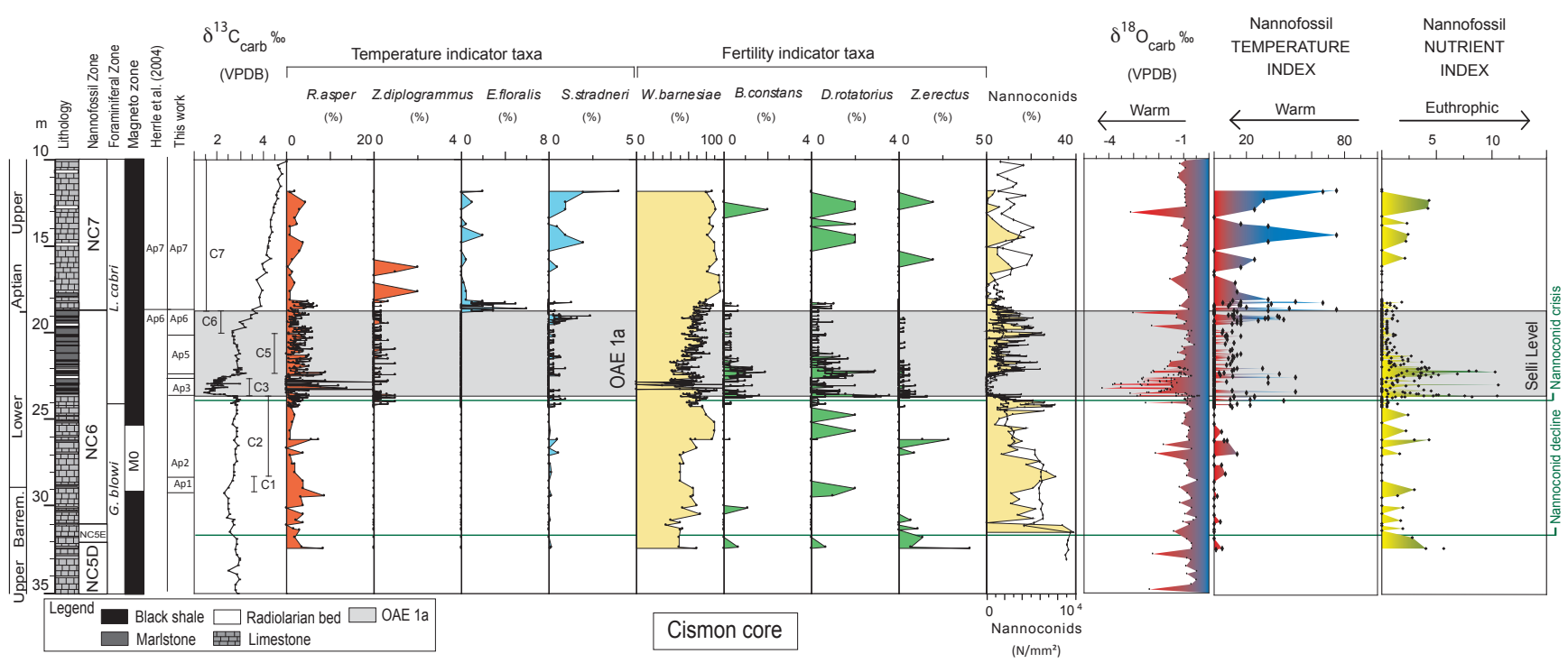

Figure 3. Cismon core: fluctuations of calcareous nannofossil temperature and fertility indicator taxa. Temperature (TI) and nutrient (NI) indices based on calcareous nannofossils (low values of the TI indicate high temperatures and vice versa; high values of the NI indicate high surface-water productivity and vice versa). $\delta^{13} \mathrm{C}$ is from Erba et al. (1999) and Méhay et al. (2009). Nannofossil and foraminiferal biostratigraphy is from Erba et al. (1999). Magnetostratigraphy is from Channell et al. (2000). Bulk $\delta^{18} \mathrm{O}$ data are from Erba et al. (2010).

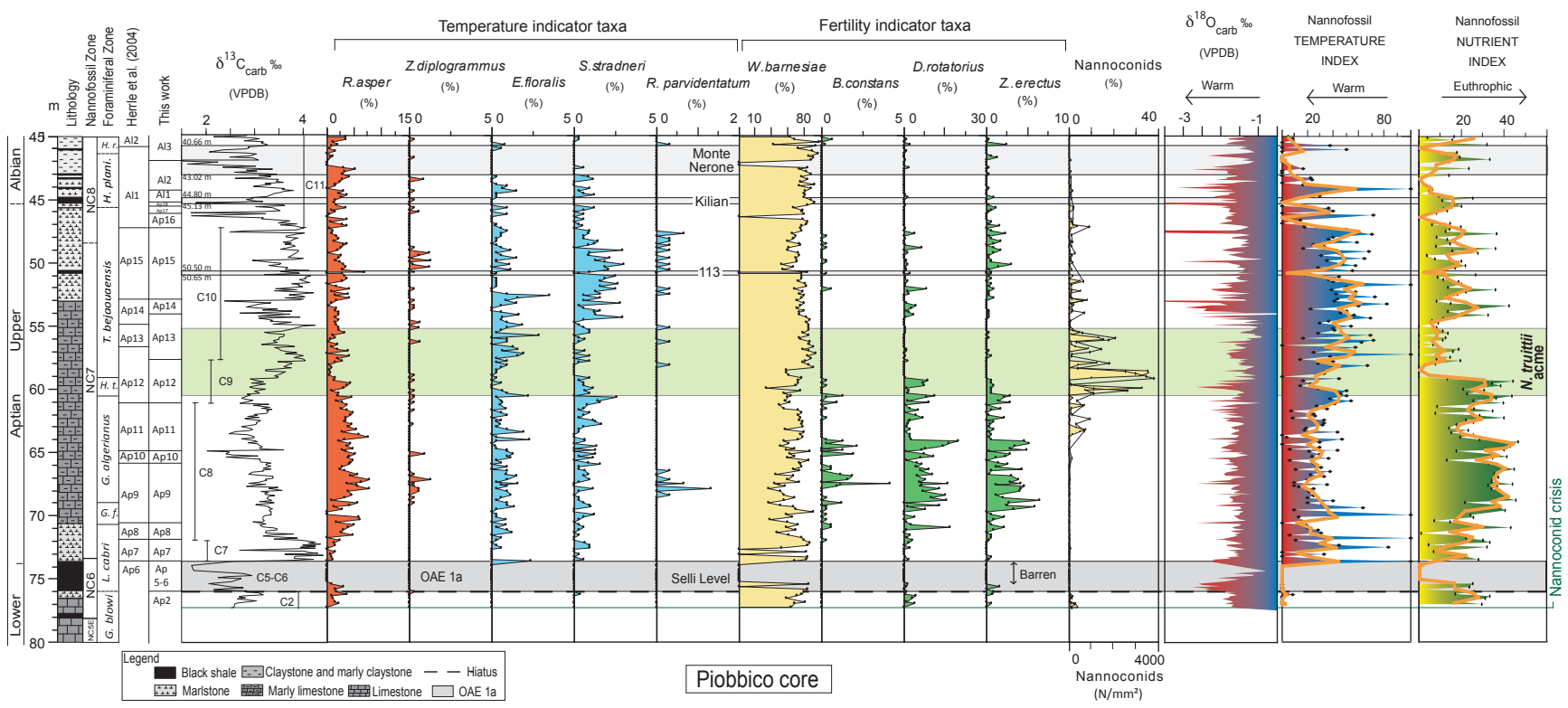

Figure 4. Piobbico core: fluctuations of calcareous nannofossil temperature and fertility indicator taxa. Temperature (TI) and nutrient (NI) indices based on calcareous nannofossils (low values of the TI indicate high temperatures and vice versa; high values of the NI indicate high surface-water productivity and vice versa). The orange curve indicates smoothed TI and NI records based on three-point moving average. $\delta^{13} \mathrm{C}$ is from Erba et al. (2015). Nannofossil and foraminiferal biostratigraphy is from Erba (1988) and Tornaghi et al. (1989). Bulk $\delta^{18} \mathrm{O}$ data are from this work.

of $58 \%$. Rhagodiscus asper ranges from 0 to $32 \%$ (mean: $6.5 \%)$, having the highest values in the lower part of the section below the Selli Level Equivalent. Zeugrhabdotus diplogrammus ranges from 0 to $2.7 \%$ (mean: $1 \%$ ). Eprolithus floralis ranges from 0 to $8.4 \%$ (mean: $0.9 \%$ ) and S. stradneri from 0 to $11.15 \%$ (mean: $2.0 \%$ ); both taxa are partic- ularly abundant in levels corresponding to segments Ap12 and part of Ap13. Biscutum constans ranges from 0 to $6.7 \%$ (mean: $0.6 \%$ ), D. rotatorius from 0 to $30 \%$ (mean: $2.4 \%$ ) and Z. erectus from 0 to $16 \%$ (mean: $1.2 \%$ ). These three species are more abundant within the lower part of the Selli Level Equivalent (segments Ap3-Ap4 of the carbon-isotope 


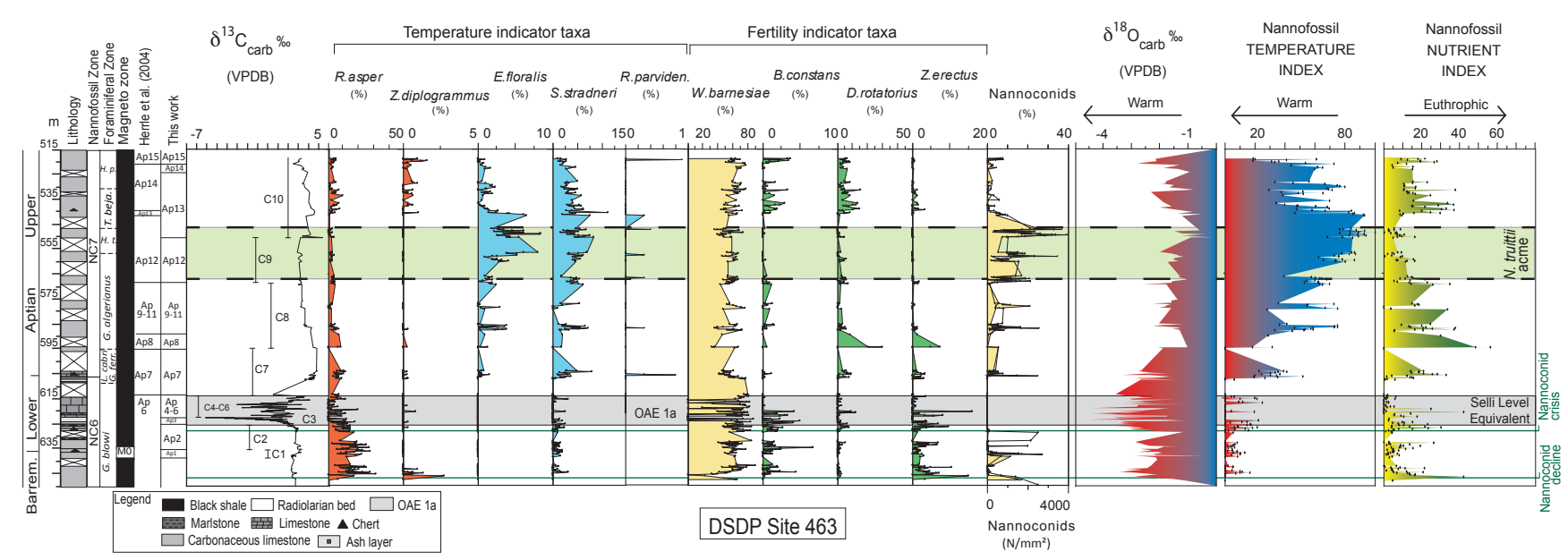

Figure 5. DSDP Site 463 Mid-Pacific Mountains: fluctuations of calcareous nannofossil temperature and fertility indicator taxa. Temperature (TI) and nutrient (NI) indices based on calcareous nannofossils (low values of the TI indicate high temperatures and vice versa; high values of the NI indicate high surface-water productivity and vice versa). $\delta^{13} \mathrm{C}$ is from Price (2003), Ando et al. (2008) and Bottini et al. (2012). Nannofossil and foraminiferal biostratigraphy is from Erba (1994) and Ando et al. (2008). Magnetostratigraphy is from Tarduno et al. (1989). Bulk $\delta^{18} \mathrm{O}$ data are from Price (2003), Ando et al. (2008) and this work.

curve). A peak is also detected around segment Ap8. Nannoconids are abundant below the Selli Level Equivalent and between 568.27 and 547 mbsf (segments Ap12 and part of Ap13), showing abundances up to $40 \%$ (relative abundance in smear slides) and $4 \times 10^{3}$ specimens $\mathrm{mm}^{-2}$ (absolute abundance in thin section), dominated by $N$. truittii, which marks the $N$. truittii acme interval. This interval is characterized by a low core recovery (35-48\%) and, consequently, the placement of the upper boundary of the $N$. truittii acme is hampered by the incomplete record. We extend the $N$. truittii acme up to $547 \mathrm{mbsf}$, where the highest nannoconid abundances are detected (Fig. 5). The sample immediately overlying is already quite low in $N$. truittii abundance and presumably corresponds to the post- $N$. truitti acme interval.

The abundance distribution of the fertility- and temperature-related taxa in the three sections shows some similarities in the Tethys and Pacific Ocean records. In the latest Barremian-earliest Aptian time interval, generally warm conditions are testified by the relative abundance of $R$. asper. A warming pulse at the onset of OAE 1 a is evident in the Cismon core, while at DSDP Site 463 R. asper shows similar or lower percentages relative to the preceding interval. In the Piobbico core the onset of OAE 1a is not preserved due to a hiatus.

The Selli Level is characterized by generally warm conditions, although palaeotemperature variability is testified by fluctuations in relative abundances of temperature-related nannofossil species in the Cismon core and at DSDP Site 463 (see Sect. 5). In the Piobbico core, most samples from the Selli Level are barren of nannofossils, and therefore negligible information was obtained.

The Selli Level interval is followed by a cooling, evidenced by the higher occurrence of the boreal taxa $E$. flo- ralis and S. stradneri. Cool-water nannofossil species, including $R$. parvidentatum, became more abundant in the late Aptian, reaching highest percentages in the late part of the $N$. truittii acme and in the immediately following interval, as documented for the Boreal Realm and the proto-North Atlantic (Herrle and Mutterlose, 2003; Mutterlose et al., 2009; McAnena et al., 2013). A relative decrease in abundance of the cool-water species is detected approaching the AptianAlbian boundary, corresponding to a gradual warming extending into the Albian.

The fertility-related taxa are generally rare, but increases in percentages of $B$. constans, D. rotatorius and $Z$. erectus are detected just before and in the early phase of OAE $1 \mathrm{a}$, suggesting a shift from oligotrophic to mesotrophic conditions. As previously partly documented in the Tethys ( $\mathrm{Lu}-$ ciani et al., 2001, 2006), a distinctive interval of higher percentages of the fertility-related species is observed at Piobbico and DSDP Site 463 in the lower upper Aptian before the $N$. truittii acme that is characterized by extremely low abundances and therefore oligotrophic conditions. A relative increase in percentages of the fertility-related species is observed after the $N$. truittii acme, although nannofossils indicate that a lower level of mesotrophy was reached relative to the early late Aptian time interval.

\subsection{Nannofossil temperature and nutrient indices}

Herrle et al. (2003a) proposed two nannofossil indices: the temperature index (TI) and the nutrient index (NI), successfully applied to selected Aptian-Albian intervals (Herrle, 2003; Herrle et al., 2003b, 2010; Tiraboschi et al., 2009; McAnena et al., 2013). Here, we adopt the TI and NI of Herrle et al. (2003a), partly modified by excluding taxa that are 
sparse and rare in the studied sections. The formulae of the indices used here are Eqs. (4) and (5):

$$
\begin{aligned}
\mathrm{TI} & =(\mathrm{Ss}+\mathrm{Ef}+\mathrm{Rp}) /(\mathrm{Ss}+\mathrm{Ef}+\mathrm{Rp}+\mathrm{Ra}+\mathrm{Zd}) \cdot 100, \\
\mathrm{NI} & =(\mathrm{Bc}+\mathrm{Dr}+\mathrm{Ze}) /(\mathrm{Bc}+\mathrm{Dr}+\mathrm{Ze}+\mathrm{Wb}) \cdot 100,
\end{aligned}
$$

where Ss stands for S. stradneri, Ef for E. floralis, Rp for $R$. parvidentatum, $\mathrm{Ra}$ for $R$. asper, $\mathrm{Zd}$ for $Z$. diplogrammus, $\mathrm{Bc}$ for $B$. constans, Dr for $D$. rotatorius, Ze for Z. erectus and Wb for W. barnesiae.

The nannofossil TI, calibrated against carbon-isotope stratigraphy, has revealed similar and synchronous changes in the Cismon core, Piobbico core and at DSDP Site 463. A complete nannofossil record through OAE 1a is available only for the Cismon core, because the Selli Level of the Piobbico core is incomplete and many samples are barren of nannofossils, while at DSDP Site 463 the top of the Selli Level Equivalent is probably not recovered and some samples are barren. In the three investigated sites, the TI and NI show the following fluctuations:

At Cismon (Fig. 3) the TI shows high-frequency fluctuations superimposed on a longer-term trend. The warmest temperatures were reached in the "nannoconid decline" and "nannoconid crisis" intervals and in the early phase of OAE 1a (corresponding to segment Ap3/C3 of the carbonisotope curve). Cooling interludes are registered within the Selli Level, especially across segments Ap4/C4 and Ap6/C6. The topmost part of the anoxic episode is marked by a shortlived warm pulse that was followed by another "cold snap" just above the Selli Level. In the overlying interval (Ap7/C7), the TI shows relatively high-amplitude fluctuations. The NI indicates that the highest surface-water fertility was recorded in the lower part of the Selli Level (segments Ap3/C3 to base of Ap5/C5). The rest of the Selli Level shows low NI. Fertility started to increase in the Ap7/C7 interval.

At Piobbico (Fig. 4), the TI shows the warmest temperatures in the lowermost part of the recovered Selli Level corresponding to the base of Ap5/C5. All samples in the Ap5/C5Ap6/C6 interval are barren of calcareous nannofossils, and therefore the TI cannot be used for relative palaeotemperature fluctuations. Corresponding to segments Ap7/C7-Ap9, a general cooling is detected (Ap8), interrupted by a brief warming. Then, from Ap9, a relative warming continued through most of Ap11. The rest of the late Aptian was characterized by a prolonged cooling episode (from top of Ap11 to top of Ap15) followed, at the end of the Aptian, by a warming trend showing two temperature peaks coinciding with the 113 Level and the Kilian Level at the Aptian-Albian boundary. The earliest Albian (Al1-Al3) shows a brief relative cooling immediately after the Kilian temperature spike, followed by a general warming. The NI exhibits relatively high values in the interval immediately preceding the Selli Level and in its lowermost portion, corresponding to the base of Ap5/C5. All samples in the Ap5/C5-Ap6/C6 interval are barren of calcareous nannofossils and therefore the NI can- not be used for illustrating palaeofertility fluctuations. Above the Selli Level, a long interval of increased fertility (Ap7Ap11) shows maximum values in the Ap9-Ap10 interval. The $N$. truittii acme is characterized by low surface-water fertility, followed by a relative increase in the NI up to Ap15. The Aptian-Albian boundary interval is marked by a decrease in the NI interrupted by a relative increase through the Kilian Level. The lowermost Albian (A12-Al3) exhibits a trend to increased fertility extending through the Albian (Tiraboschi et al., 2009).

At DSDP Site 463 (Fig. 5), the TI indicates that warm temperatures were reached before the onset of OAE 1a close to the "nannoconid decline" and "nannoconid crisis" episodes. Another significant warming correlates with segment Ap3/C3. Relative cooling interludes are registered within the Selli Level Equivalent, in segments Ap4/C4 and Ap6/C6. During the late Aptian, a long cooling (Ap7-Ap13) is registered with the coolest temperatures recorded from the top of Ap12 to the base of Ap13, at the top of the N. truittii acme interval and the interval immediately above it. The NI indicates relatively high values in the interval preceding the Selli Level Equivalent, particularly across the "nannoconid decline" and "nannoconid crisis". Two NI peaks are recorded in the $\mathrm{Ap} 3 / \mathrm{C} 3$ and at the base of Ap5/C5, respectively. Low NI is detected in the rest of the Selli Level Equivalent. An increase in the NI starts in Ap7 and continues up to the base of Ap12, with a maximum corresponding to Ap8. A decrease is then recorded during the $N$. truittii acme interval, followed by a relative increase.

\subsection{Oxygen-isotope fluctuations}

The three oxygen-isotope records are somewhat scattered, and probably reflect a contribution from diagenetic cement. However, $\delta^{18} \mathrm{O}$ trends are reproduced at the three studied sites independently of lithology, and nannofossil preservation is persistently moderate; we conclude, therefore, that the oxygen-isotope records contain a primary palaeotemperature signal only marginally modified by lithification. Although $\delta^{18} \mathrm{O}$ values may be to some extent controlled by salinity fluctuations, there is no independent evidence of significant salinity changes during the Aptian. As discussed by Weissert and Erba (2004), Early Cretaceous oxygen-isotope records show similar changes at various settings and in different oceanic basins. All data collected so far suggest a positive correlation between $\delta^{18} \mathrm{O}$ trends and palaeotemperature reconstructions based on palaeontological and/or geochemical (e.g. TEX ${ }_{86}$ ) data. Conversely, there is no reliable information of significant palaeosalinity changes. Moreover, the studied sections are pelagic in nature and salinity changes may be an issue in more restricted basins but not in open oceanic environments.

The main trends (Figs. 3-5) are summarized as follows:

Along segments $\mathrm{Ap} 1 / \mathrm{C} 1$ and $\mathrm{Ap} 2 / \mathrm{C} 2$ the isotopic ratios are relatively stable, being $\sim-2 \%$ at DSDP Site 463 , 
$-1.5 \%$ at Piobbico and $-1 \%$ at Cismon. At the end of segment Ap2/C2 values start to decrease, reaching $-4 \%$ o in correspondence to the negative carbon-isotope excursion (segment Ap3/C3). At Cismon, the decreasing trend is interrupted by a short-lived $(\sim 35 \mathrm{kyr}$ according to Malinverno et al., 2010) interval of higher values $(-1.5 \%$ ) . At segment Ap4/C4, the $\delta^{18} \mathrm{O}$ values start increasing and in the middle part of the Selli Level (segment Ap5/C5) they fluctuate: between -1 and $-2 \%$ at Cismon, between -1 and $-3 \%$ o at Piobbico and between -1 and $-4 \%$ at DSDP Site 463 . Corresponding to segment Ap6/C6, $\delta^{18} \mathrm{O}$ values are relatively stable between -1 and $-2 \%$. Starting from segment Ap7/C7, oxygen isotopes illustrate progressively increasing ratios reaching $\sim-1 \%$ around the $N$. truittii acme interval and then decrease to a minimum of $\sim-3 \%$ close to the Aptian-Albian boundary. With respect to coeval sediments in the Tethys and Pacific oceans, we notice that the oxygenisotope values of the Cismon are greater by $1 \%$.

\subsection{TEX TE6 $_{86}$}

A total of 32 samples from the Cismon core have been analysed for TEX 86 , of which 17 contained detectable amounts of GDGTs (Table $\mathrm{S} 1$ in the Supplement). TEX ${ }_{86}$ data for a number of sediments were excluded as they contained relatively mature organic matter, i.e. the hopane $22 \mathrm{~S} /(22 \mathrm{~S}+22 \mathrm{R})$ ratio was $>0.2$ (van Breugel et al., 2007), at which level $\mathrm{TEX}_{86}$ values will become biased towards lower temperatures (Schouten et al., 2004). Nearly all sediments have BIT values $<0.3$, suggesting relatively low input of soil-derived GDGTs, and thus no bias of the TEX TE $_{86}$ (Weijers et al., 2006). The values obtained for the OAE 1a interval (Figs. 2, 7) comprise one sample with a $\mathrm{TEX}_{86}$ value of 0.57 indicative of $\sim 22{ }^{\circ} \mathrm{C}$ sea-surface temperature (SST) and corresponding to the most negative $\delta^{13} \mathrm{C}$ values (segment $\mathrm{Ap} 3 / \mathrm{C} 3$ ). The rest of segment $\mathrm{Ap} 3 / \mathrm{C} 3$ is characterized by values from 0.67 to 0.61 (SST $=\sim 24-27^{\circ} \mathrm{C}$ ). Segments $\mathrm{Ap} 4 / \mathrm{C} 4$ and Ap5/C5 are characterized by relatively stable values lying between 0.66 and $0.64\left(\mathrm{SST}=\sim 25-26^{\circ} \mathrm{C}\right.$ ). Corresponding to segment Ap6/C6, one sample gives a $\mathrm{TEX}_{86}$ value of 0.58 $\left(\mathrm{SST}=\sim 22.5^{\circ} \mathrm{C}\right)$ and the following one of $0.64(\mathrm{SST}=\sim$ $\left.25.5^{\circ} \mathrm{C}\right)$.

\section{Discussion}

\subsection{Long- and short-term temperature fluctuations during the Aptian}

Our nannofossil data show long-term temperature variations that are comparable with the results of previous studies based on various temperature proxies (i.e. calcareous nannofossils, palynomorph, oxygen isotopes and $\mathrm{TEX}_{86}$ ). Although, as discussed above, the oxygen isotopic record is partly affected by diagenetic overprints inducing some scattering of the data, some general trends are present in both the Tethys and Pacific
Ocean records. The one-to-one correlation of the nannofossil TI and $\delta^{18} \mathrm{O}$ highlights some discrepancies although the major episodes of warming and cooling are registered by both proxies.

We used the three-point moving average of the TI in the three studied sections to compile a composite nannofossilderived palaeotemperature curve for characterization of climate changes during the Aptian (Fig. 6). As far as the TI is concerned, warming is essentially determined by very low percentages or absence of cold-water species and, consequently, it is impossible to estimate the extent of the warming when the TI is zero (highest temperature).

\subsubsection{Long-term temperature fluctuations}

Warm temperatures were characterizing the latest Barremian-earliest Aptian (Figs. 6, 7). The highest temperatures, based on TI and the abundance maximum of $R$. asper, are recorded in the core of the negative carbon-isotope interval (segment Ap3/C3), as also documented in other sections in the Tethys (e.g. Menegatti et al., 1998; Hochuli et al., 1999; Luciani et al., 2001; Bellanca et al., 2002; Jenkyns, 2003, 2010; Millán et al., 2009; Erba et al., 2010; Keller et al., 2011; Stein et al., 2011; Bottini et al., 2012; Hu et al., 2012; Husinec et al., 2012), Vocontian Basin (e.g. Moullade et al., 1998; Kuhnt et al., 2011), Boreal Realm (Mutterlose et al., 2010; Bottini and Mutterlose, 2012; Pauly et al., 2013; Mutterlose and Bottini, 2013), Russian Platform (Zakharov et al., 2013) and Pacific Ocean (e.g. Jenkyns, 1995; Price, 2003; Schouten et al., 2003; Ando et al., 2008; Bottini et al., 2012). Warm conditions persisted through OAE 1a, although fluctuations are detected, as discussed below. A major cooling, coeval with segment Ap7/C7, marks the end of global anoxia; it is followed by a relatively warm phase preceding a major long-lasting cooling episode starting during segment Ap8 and extending through most of the late Aptian. Minimum temperatures were reached at the end of and immediately after the $N$. truittii acme, in agreement with the cooling (of $\sim 4^{\circ} \mathrm{C}$ down to $\sim 28^{\circ} \mathrm{C}$ ) indicated by $\mathrm{TEX}_{86}$ reconstructed from the proto-North Atlantic (McAnena et al., 2013). Further evidence of significant cooling during the late Aptian derives from the occurrence of the Boreal (cold water) species $R$. parvidentatum at low latitudes as documented here for the Piobbico core and DSDP Site 463 (Figs. 4, 5, 7), and in the Vocontian Basin, North Sea and proto-North Atlantic Ocean (Herrle and Mutterlose, 2003; Rückheim et al., 2006; Herrle et al., 2010; McAnena et al., 2013). In the latest Aptian (upper part of segment Ap15), temperatures show a relative increase, with warm peaks at the 113 Level and Kilian Level Equivalent.

\subsubsection{Climate variability during OAE 1a}

The integration of nannofossil TI and oxygen-isotope data allows the identification of a sequence of temperature vari- 


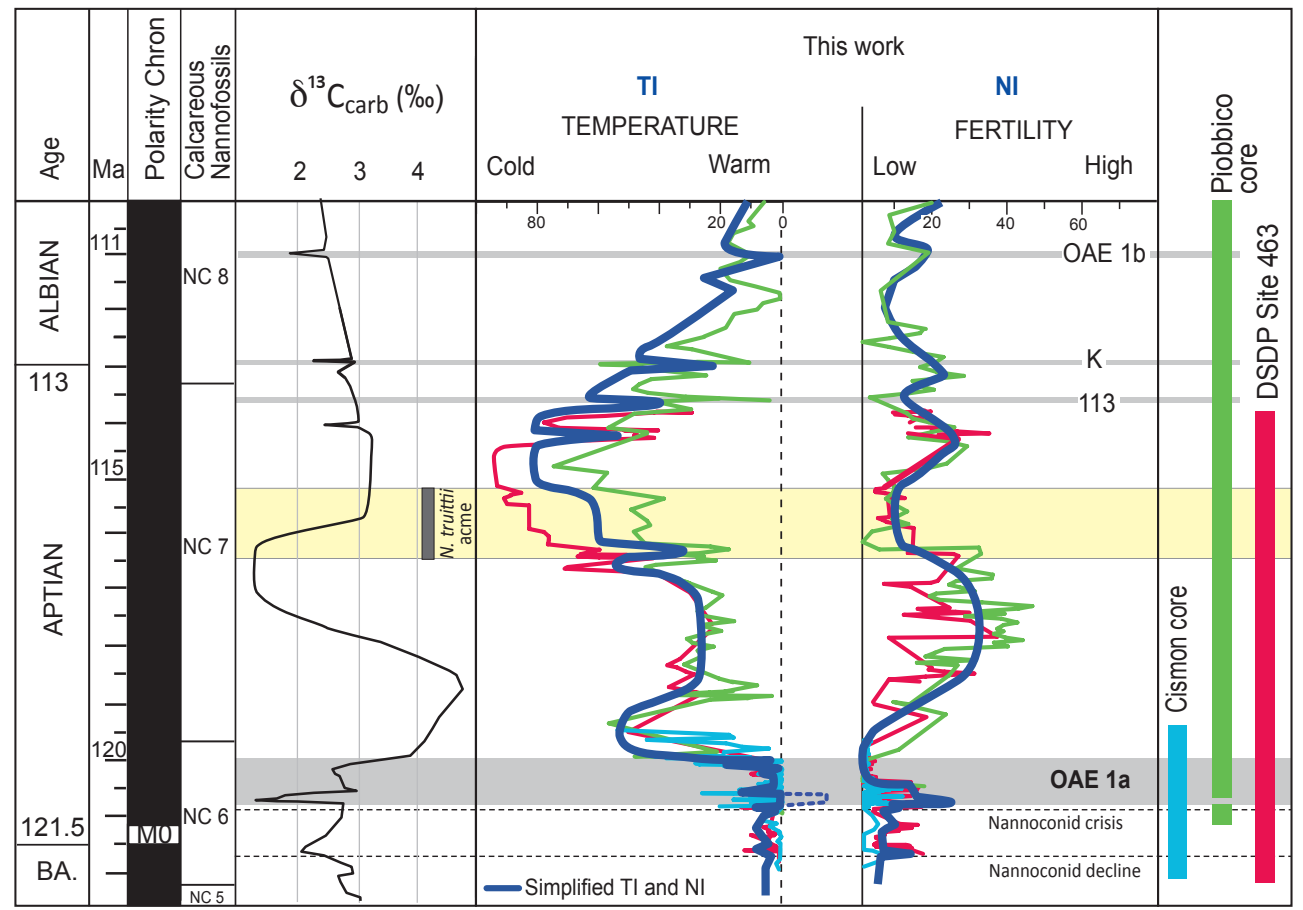

Figure 6. Composite nannofossil TI and NI curves extrapolated from the three-point moving averages of the TI and NI in the three studied sections for the Aptian including the Aptian-Albian boundary interval (this work) and the earliest Albian (from Tiraboschi et al., 2009). The dashed TI spike in the earliest part of OAE 1a takes into account the relative abundance of $R$. asper, showing a maximum at this level. Bio-chemo-magneto stratigraphy after Erba et al. (2015). Numerical ages are based on the timescale of Malinverno et al. (2012).

ations within OAE 1a in the Cismon core and at DSDP Site 463 (Fig. 8). In the Piobbico core the hiatus at the base of the Selli Level and the absence of nannofossils in most samples across the black shale interval hamper the identification of short-term temperature changes during OAE 1a. Data from the Cismon core provide a high-resolution and complete record of the latest Barremian-early Aptian time interval, reproducible at DSDP Site 463, although here the recovery is incomplete and some samples are barren of nannofossils.

The latest Barremian-earliest Aptian time interval was characterized by warm temperatures (Fig. 8). After a warming pulse at the onset of OAE 1a (Interval A), a brief $(\sim 35 \mathrm{kyr})$ cooling interlude interrupted warm conditions corresponding to the interval of minimum $\delta^{13} \mathrm{C}$ values (Interval B). It was followed by a maximum warming in the core of segment Ap3/C3 (Interval C). A cooling episode (Interval D) coincides with segment Ap4/C4 and base Ap5/C5. A cool snap across segment Ap4/C4 interrupting the main warming has also been detected in the Vocontian Basin (Kuhnt et al., 2011; Lorenzen et al., 2013), Tethys (Menegatti et al., 1998; Luciani et al., 2001; Stein et al., 2011) and Turkey (Hu et al., 2012). Intermediate climatic conditions (intervals E-G) during segment Ap5/C5 were interrupted by a warming interlude (Interval F). Warmer temperatures (Interval H) preceded a more prominent cooling (Interval I) correlating with the latest part of OAE 1a and corresponding to segment Ap6/C6. The end of anoxia was marked by a shortlived warming (Interval L) and a further major cooling (Interval M) coinciding with the onset of segment Ap7/C7.

The correlation of oxygen-isotope and calcareous nannofossil data sets with SST estimates from TEX $_{86}$ is difficult since the $\mathrm{TEX}_{86}$ data available for OAE 1a have a much lower resolution and provide relatively scattered records. The new $\mathrm{TEX}_{86}$ data for the Cismon core are suggestive of SSTs ranging between 22 and $27{ }^{\circ} \mathrm{C}$. The lowermost data point, which corresponds to Interval B (core of segment Ap3/C3), indicates an SST of $\sim 22^{\circ} \mathrm{C}$, which is the coolest value for the studied interval and matches well with cooler conditions reconstructed from other data. The SST values for the following three data points are rather puzzling: two indicate temperatures of $\sim 23-25^{\circ} \mathrm{C}$ and fall in Interval $\mathrm{C}$ (end of segment Ap3/C3) - the warmest of OAE 1a - while the third data point shows almost $27^{\circ} \mathrm{C}$ although it falls in Interval D (segment Ap4/C4), interpreted to correspond to a time of relative cooling. The rest of the samples, encompassing intervals E-H (segment Ap5/C5), and representing minor temperature fluctuations, fall between 25 and $27^{\circ} \mathrm{C}$. We identify one more discrepancy in the relatively low estimated $\operatorname{SST}\left(22.5^{\circ} \mathrm{C}\right)$ for one sample falling in Interval $\mathrm{H}$ (onset of segment Ap6/C6), suggested by TI and oxygen isotopes to be a relatively warm interlude. 


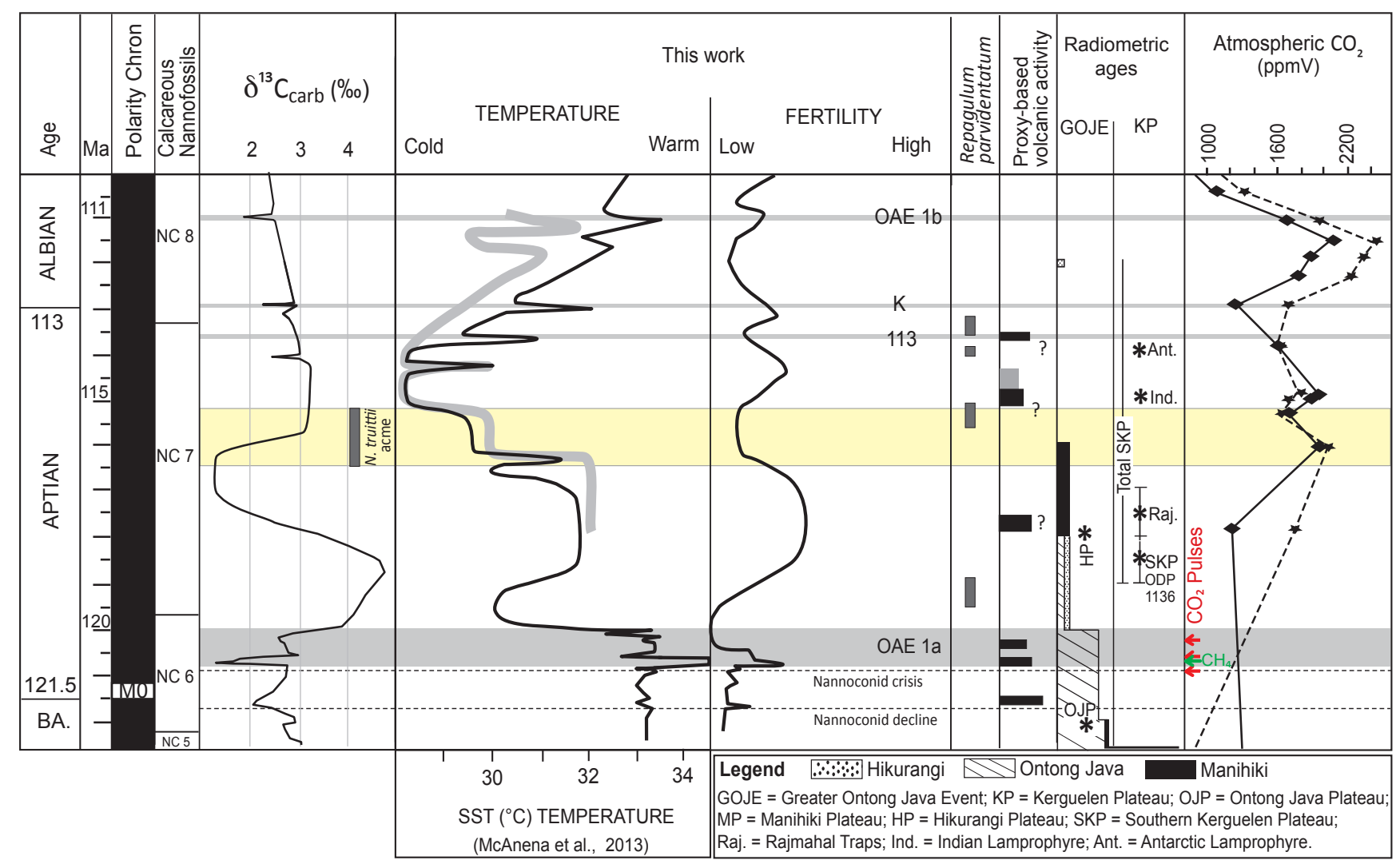

Figure 7. Nannofossil-based temperature and nutrient variations reconstructed from the three-point moving averages of the TI and NI in the three studied sections (as in Fig. 6). The thick-grey curve represents SSTs from McAnena et al. (2013). Bio-chemo-magneto stratigraphy after Erba et al. (2015). Numerical ages are based on the timescale of Malinverno et al. (2012). Multiproxy-based volcanic phases and radiometric ages of the Greater Ontong Java Event (GOJE) and Kerguelen Plateau (KP) LIPs are from Erba et al. (2015). Atmospheric $\mathrm{CO}_{2}$ : $\mathrm{Li}$ et al. (2014) reporting estimates based on highly smoothed average $\delta^{13} \mathrm{C}_{\mathrm{r}}$ (diamonds) and on isotopic data from Tethyan pelagic sediments (stars). The volcanogenic $\mathrm{CO}_{2}$ (red arrows) and $\mathrm{CH}_{4}$ (green arrow) pulses are from Méhay et al. (2009) and Erba et al. (2010).

Another problem of the $\mathrm{TEX}_{86}$ data of the Cismon core is related to the SSTs, which are $\sim 5$ to $8^{\circ} \mathrm{C}$ lower compared with the $\mathrm{TEX}_{86}$ records from other sites. TEX $\mathrm{T}_{86}$ data from DSDP Site 463 cover the Ap4/C4-Ap6/C6 interval and range between 31 and $34^{\circ} \mathrm{C}$ (recalibrated from Schouten et al., 2003, using Eq. 2). At Shatsky Rise, temperatures fall between 30 and $35^{\circ} \mathrm{C}$ (recalibrated values from Dumitrescu et al., 2006, using Eq. 2). Here, two cooling interludes are detected: the first cooling by $4{ }^{\circ} \mathrm{C}$ down to $30^{\circ} \mathrm{C}$ was during segment Ap4/C4 and corresponds to the cooling of our Interval $\mathrm{D}$. The second cooling of 5 down to $30^{\circ} \mathrm{C}$ seems to corresponds to segment Ap6/C6 and possibly reflects the cooling of Interval I. In the Lower Saxony Basin, SSTs indicate a distinctive warming during OAE 1a (segment C3-C6), with $\mathrm{TEX}_{86}$ temperature estimates of $31-34^{\circ} \mathrm{C}$. The TEX 86 data for the interval following OAE 1a (the C7 segment) reveal stable SSTs around $30^{\circ} \mathrm{C}$ (Mutterlose et al., 2010, 2014).

We notice that, although the temperature variability $\left(\Delta=\sim 4-5^{\circ} \mathrm{C}\right.$ ) is similar in all sites, the absolute temperatures at Cismon are generally $5-8^{\circ} \mathrm{C}$ lower than at DSDP Site 463, Shatsky Rise and Lower Saxony Basin. For Cis- mon, the highest (coolest temperature) $\delta^{18} \mathrm{O}$ values are also $\sim 1 \%$ o greater than those registered at DSDP Site 463 and $\sim 0.5 \%$ greater than those at Piobbico. Generally cooler temperatures for Cismon could be explained by different latitudinal settings, the Cismon site being at $\sim 30^{\circ} \mathrm{N}$, Shatsky Rise at an almost equatorial position and DSDP Site 463 at $\sim 20^{\circ} \mathrm{S}$. However, this seems not to apply to the boreal section $\left(39^{\circ} \mathrm{N}\right)$ characterized by the highest $\left(\sim 35^{\circ} \mathrm{C}\right)$ SST. It has been shown in several modern settings that TEX $_{86}$, although calibrated against SST, may sometimes reflect changes in subsurface-water temperatures as well (e.g. Huguet et al., 2007; Lopes dos Santos et al., 2010), possibly because the source organisms, Thaumarchaeota, also reside in the deeper thermocline, where nutrients such as ammonia might be available. Perhaps the most likely explanation for this discrepancy may be that the $\mathrm{TEX}_{86}$ values from the Cismon core are already affected by the higher level of thermal maturity (i.e. hopane $22 \mathrm{~S} /(22 \mathrm{~S}+22 \mathrm{R})$ ratios of $0.1-0.2)$. It has been documented that destruction of GDGTs during thermal maturation processes results in lower $\mathrm{TEX}_{86}$ values due 
to the fact that GDGTs with cyclopentane moieties are thermally less stable (Schouten et al., 2004).

\subsection{Long- and short-term changes in surface-water fertility}

The nannofossil NI exhibits similarities between the three studied sites (simplified in Figs. 6 and 7, where nannofossil data are calibrated against the $\delta^{13} \mathrm{C}$ curve, adopting the timescale of Malinverno et al., 2012). A synthesis curve was reconstructed based on the three-point moving average of the NI in the three studied sections. The latest Barremianearliest Aptian interval is characterized by low to intermediate NI values suggestive of oligotrophic conditions, with three relative increases associated with the "nannoconid decline", the "nannoconid crisis" and the interval in between. The onset of OAE 1a was marked by increasing fertility, which reached a first peak in the core interval of the negative carbon-isotope excursion (segment Ap3/C3). A decrease in surface-water fertility characterized the rest of the Selli Level (segments Ap4/C4-Ap6/C6) and extents to the portion immediately overlying the black shale interval. A shift to mesoto eutrophic conditions is detected from the uppermost part of segment Ap7: both at DSDP Site 463 and in the Piobbico core, maximum NI values are reached within segment Ap8 showing higher fertility conditions relative to those recorded during OAE 1a. Fertility shows a decrease starting just before the $N$. truittii acme interval characterized by a minimum of the NI curve. The latest Aptian is then characterized by intermediate NI values, continuing into the earliest Albian.

The early Aptian has been generally seen as a time of warm and humid climate, mainly responsible for accelerated continental weathering, and consequent important nutrient fluxes to the ocean sustaining high productivity (e.g. Leckie et al., 2002; Erba, 2004; Föllmi, 2012). It has also been proposed that higher fertility in the global ocean was triggered directly by submarine igneous events that introduced enormous quantities of biolimiting metals within hydrothermal plumes (e.g. Larson and Erba, 1999; Leckie et al., 2002; Erba, 2004).

Peaks in the NI are detected at the levels of the "nannoconid decline" ( $\sim 1$ Ma before OAE 1 a) and the "nannoconid crisis". This relationship is in agreement with the interpretation of nannoconids as oligotrophic taxa, which suffered during episodes of increased surface-water fertility. Their virtual absence during the early phase of OAE 1a has been interpreted as the result of widespread meso- to eutrophic conditions (e.g. Coccioni et al., 1992; Bralower et al., 1994; Erba, 1994, 2004; Premoli Silva et al., 1999) combined with excess $\mathrm{CO}_{2}$ in the ocean-atmosphere system (Erba and Tremolada, 2004; Erba et al., 2010).

As far as the OAE 1a interval is concerned, the fluctuations in surface-water fertility reconstructed in our work are in agreement with other studies on calcareous nannofossils from the Tethys, Boreal Realm and Atlantic Ocean. Further- more, other proxies, for example palynomorphs (Hochuli et al., 1999) and phosphorus (e.g. Föllmi et al., 2006; Föllmi and Gainon, 2008; Stein et al., 2012), support this interpretation.

\subsection{Climate and environmental changes and their relation to igneous-tectonic events during the Aptian}

Our data confirm a relationship between major volcanic episodes and climate change, with associated (or subsequent) perturbations in ocean chemistry, structure and fertility. Specifically, the construction of the OJP Large Igneous Province (LIP), documented in the Os-isotopic record (Tejada et al., 2009; Bottini et al., 2012), Pb isotopes (Kuroda et al., 2011) and biomarkers (Méhay et al. 2009), suggestive of a stepwise accumulation of volcanogenic $\mathrm{CO}_{2}$ in the atmosphere (Figs. 7, 8), correlates in time with OAE 1a and was marked by global warming at the onset of the mid-Cretaceous greenhouse (e.g. Larson and Erba, 1999; Jenkyns, 2003). As documented by Méhay et al. (2009), a short-lived event of possible methane hydrate dissociation probably promoted a $\sim 100 \mathrm{kyr}$ long interval of accelerated continental weathering, temporarily reducing the $\mathrm{CO}_{2}$ concentrations and inducing a subsequent cooling interlude (Interval B, in Fig. 8) with an estimated duration of $\sim 35 \mathrm{kyr}$ (Bottini et al., 2012). The next interval, marked by a maximum warming, coincided with the beginning of the most intense volcanic phase of OJP (Bottini et al., 2012). This correspondence is suggestive of a (super)greenhouse climate triggered by excess volcanogenic $\mathrm{CO}_{2}$. The rest of OAE 1a was accompanied by climate variability including cooling interludes. Termination of widespread anoxia-dysoxia coincided with the end of the main emplacement of the OJP (Tejada et al., 2009; Bottini et al., 2012) and a major cooling.

Large-scale igneous-tectonic events took place also during the late Aptian, but their causal impact on climate changes are less obvious, since palaeotemperatures were generally cooler. We notice that submarine volcanism of the Greater Ontong Java Event (GOJE) and of the early phase of Kerguelen Plateau correlates with global warming, but subaerial volcanism (Kerguelen Plateau LIP) was associated with relatively cool conditions (Fig. 7). In addition to magmatic fluxes of different orders of magnitude (lower for Kerguelen; see Eldholm and Coffin, 2000), subaerial volcanism probably injected ashes and gases into the atmosphere inducing short-term cooling associated with individual degassing phases. Feedbacks related to atmospheric $\mathrm{CO}_{2}$ drawdown via accelerated weathering were probably most significant, as also suggested by $\mathrm{Ca}$ isotopes (Blättler et al., 2011). On the basis of pedogenic calcretes from South Korea, Hong and Lee (2012) documented a decrease in $\mathrm{CO}_{2}$ concentrations from $\sim 1000$ to $\sim 500 \mathrm{ppmV}$ for an interval in the late Aptian corresponding, as discussed above, to relatively cooler temperatures. However, these data present 


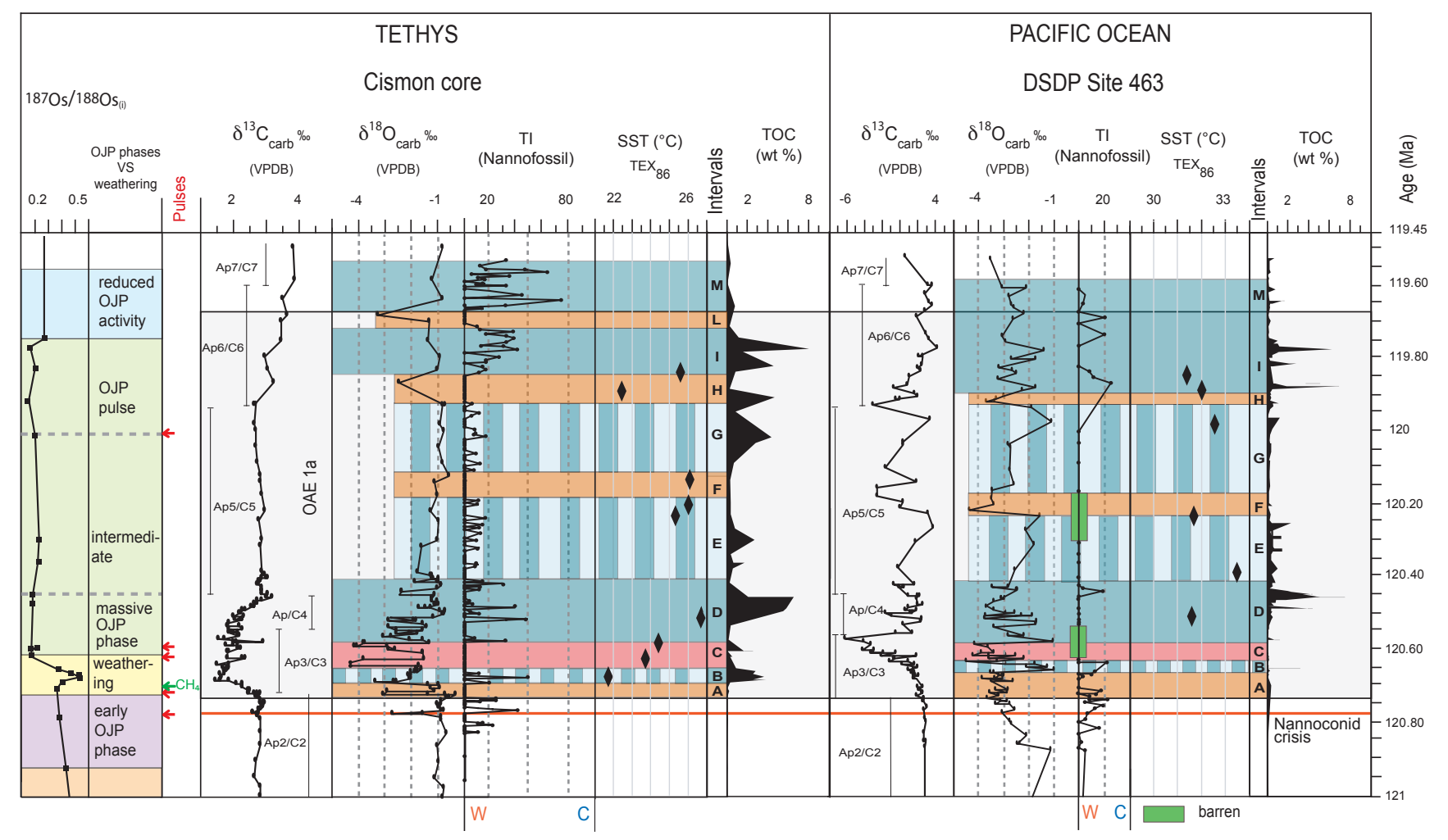

Figure 8. Nannofossil temperature index (TI), TEX $_{86}$ and oxygen-isotope values for the Cismon core and DSDP Site 463 plotted against chemostratigraphy. The age determination is based on the cyclochronology available for the Cismon core (Malinverno et al., 2010$)$. $\delta^{13} \mathrm{C}$ data after Erba et al. (1999) and Méhay et al. (2009) for the Cismon core; Price (2003), Ando et al. (2008) and Bottini et al. (2012) for DSDP Site 463. Bulk $\delta^{18} \mathrm{O}$ data after Erba et al. (2010) for the Cismon core; Price (2003), Ando et al. (2008) and this work for DSDP Site 463. TOC after Erba et al. (1999) and Bottini et al. (2012) for the Cismon core; Ando et al. (2008) for DSDP Site 463 . TEX 86 after Schouten et al. (2003) for DSDP Site 463; this work for the Cismon core (SST calculated using the equation of Kim et al., 2010). The Os-isotope curve (Bottini et al., 2012) is reported on the left, as well as the volcanogenic $\mathrm{CO}_{2}$ pulses (red arrows) reconstructed by Méhay et al. (2009) and Erba et al. (2010). The intervals A-M represent the climatic interludes (warming and cooling) reconstructed in this work.

a large uncertainty in the age assignment. Recently published data by Li et al. (2014), from similar continental facies in south-east China spanning the same age, are suggestive of higher values. Specifically, here we present (Fig. 7) a revised plot of $\mathrm{Li}$ et al. (2014) data based on the Malinverno et al. (2012) timescale, which indicates progressively increasing $\mathrm{CO}_{2}$ concentrations from $\sim 1000$ up to $\sim 2000 \mathrm{ppmV}$ across the $N$. truittii acme interval despite a general cooling trend. In correspondence to the lowest temperatures reached in the latest Aptian, $\mathrm{CO}_{2}$ estimates decrease to $\sim 1600 \mathrm{ppmV}$. The following early Albian warming trend was instead paralleled by increasing $\mathrm{CO}_{2}$ concentrations up to $2500 \mathrm{ppm}$.

The long-lasting cool conditions of the late Aptian have been recently quantified using $\mathrm{TEX}_{86}$ data (McAnena et al., 2013), which indicate a total decrease in palaeotemperatures of $\sim 4-5^{\circ} \mathrm{C}$ (from $\sim 32$ to $\sim 27.5^{\circ} \mathrm{C}$ ) in the equatorial proto-Atlantic Ocean followed by a warming $\left(\sim 4^{\circ} \mathrm{C}\right)$ linked to the earliest Albian OAE 1b. The late Aptian trends of our nannofossil TI curve are similar to these TEX $_{86}$ - reconstructed SST changes (Fig. 7), so we tentatively use the values of McAnena et al. (2013) to estimate climate variations through the Aptian starting from the nannofossilderived temperature fluctuations. In particular, the TEX ${ }_{86}-$ reconstructed SSTs and the TI curve are well overlapping in the interval marked by the stepwise cooling across the $N$. truittii acme and in the immediately following interval. Therefore, we use this best fitting to extrapolate absolute values from the nannofossil temperature curve in the latest Barremian-earliest Albian interval (Fig. 7).

The warming at the onset of OAE 1a corresponds to an increase of $1.5-2{ }^{\circ} \mathrm{C}$ followed by a first cooling of $\sim 2{ }^{\circ} \mathrm{C}$. As far as OAE $1 \mathrm{a}$ is concerned, the SST variability estimated from the TI $\left(1.5-2^{\circ} \mathrm{C}\right)$ differs from the TEX $\mathrm{X}_{86}$ estimates of $4-5^{\circ} \mathrm{C}$. The prominent cooling at the end of global anoxia corresponds to a decrease of $\sim 3^{\circ} \mathrm{C}$, followed by a relative warming of $\sim 2{ }^{\circ} \mathrm{C}$, and the coolest interval in the late Aptian is marked by a further total decrease of $\sim 4^{\circ} \mathrm{C}$. Starting in the latest Aptian, an increase in TI-derived temperatures register a warming of $5-6^{\circ} \mathrm{C}$, punctuated by "hyperthermals", and 
culminating in highest values in OAE $1 \mathrm{~b}$. We notice that the increase in TI palaeotemperatures reconstructed for the latest Aptian-earliest Albian is $\sim{ }^{\circ} \mathrm{C}$ higher than the SST curve, although the trend is very similar.

Volcanically linked climate change seems closely connected to nutrient recycling and ocean fertilization (e.g. Weissert et al., 1998; Föllmi et al., 2006). Different eruption styles and duration, as well as magma composition and quantity, presumably produced diverse weathering rates and introduction of biolimiting metals (Larson and Erba, 1999; Leckie et al., 2002; Erba et al., 2015). Although calcareous nannoplankton are but one group of primary producers and they thrive under oligotrophic-mesotrophic conditions, the nannofossil NI can be used to trace the trophic levels of surface waters in the past. As synthesized in Fig. 7, the nannofossil NI suggests that fertility fluctuations were strongly coupled with climate change in the early Aptian, but less so in the late Aptian. Fertility fluctuations could be due to differential weathering rates. During OAE 1a, greenhouse conditions generated by repetitive volcanogenic $\mathrm{CO}_{2}$ emissions (e.g. Méhay et al., 2009; Erba et al., 2010) might have increased weathering rates and thereby the supply of nutrients. We see a correspondence between maximum warming and higher surface-water fertility. In addition, the largest submarine volcanic pulses at the beginning of OAE $1 \mathrm{a}$ and in the mid-late Aptian seem to have introduced biolimiting metals during submarine plateau construction (Larson and Erba, 1999; Leckie et al., 2002; Erba et al., 2015). The nutrients presumably stimulated primary productivity with consequent consumption of oxygen through organic matter and metal oxidation, hence promoting anoxic conditions. The upper part of the Selli Level has high TOC content (Fig. 8), indicating that productivity and preservation of organic matter was relatively high. The oligotrophic conditions suggested by the NI are explained by biomarker data and nitrogen stable isotopes, indicating $\mathrm{N}$-fixing cyanobacteria as the main primary producers during OAE 1a (Kuypers et al., 2004; Dumitrescu and Brassell, 2006). Their $\mathrm{N}$ fixation potentially provided $\mathrm{N}$ nutrients for the rest of the oceanic biota and presumably was the key process in the production of organic matter, maintaining higher productivity through OAE 1a up to the end of anoxic conditions. The accumulation and burial of organic matter would have progressively acted as storage for excess $\mathrm{CO}_{2}$, leading to lower temperatures and, possibly, to the termination of OAE 1a under less active (or ceased) OJP volcanism. We notice that the two more intense cooling interludes across OAE 1a correspond to levels with relatively high TOC content ( $>4 \%$ ), suggesting that the burial of organic matter may have acted as a reservoir for excess $\mathrm{CO}_{2}$, thus temporarily mitigating greenhouse conditions.

Among Cretaceous calcareous nannofloras, nannoconids are interpreted as specific to the lower photic zone, associated with a deep nutricline, so that they thrived when surface waters were characterized by oligotrophic conditions (Erba, 1994, 2004). The record of nannoconid distribution com- pared with the nannofossil NI confirms this hypothesis for the entire Aptian interval: the "nannoconid crisis" correlates with an increase in the NI, while the return of nannoconids following deposition of the Selli Level and the N. truittii acme corresponds to minima in the NI curve. We stress the fact that nannoconid abundance does not unequivocally correlate with climate change, at least in the Aptian, because the "nannoconid crisis" coincides with major warming while the final nannoconid disruption (the end of the N. truittii acme) corresponds to the most severe cooling.

These data contradict the interpretation of McAnena et al. (2013) for the nannoconid failure due to cold conditions in the late Aptian and imply a different explanation for abundance changes of these rock-forming nannofossils. We believe that volcanically induced $\mathrm{CO}_{2}$ concentrations played a key role in nannoconid calcification, regardless of climatic conditions (Erba, 2006). Both the OJP and Kerguelen LIPs emitted huge quantities of $\mathrm{CO}_{2}$ that arguably provoked ocean acidification. We emphasize that the prolonged cooling in the late Aptian promoted $\mathrm{CO}_{2}$ absorption in the ocean and acidification. The $N$. truittii acme interval corresponds to temperate conditions following a cooling episode associated to segment Ap8 and preceding the most intense decrease in palaeotemperature in the late Aptian (Fig. 7). The coeval extremely low metal abundance (Fig. 7) is further evidence of seemingly quiescence in volcanism and reduced atmospheric $\mathrm{CO}_{2}$, promoting favourable conditions for the thriving of heavily calcified forms. The nannoconid crises, including their final collapse in the latest Aptian, could thus be viewed as failures in biocalcification. Similarly, the major reduction in size, decrease in abundance, and species turnover documented for planktonic foraminifers (Huber and Leckie, 2011), which is coeval with the final nannoconid decline and a nannofossil turnover, might be the response of calcareous zooplankton to volcanically triggered ocean acidification. Similar responses of calcareous zooplankton were documented for OAE 1a and OAE 2 with a major decrease in planktonic foraminiferal abundance and diversity as well as evolutionary turnover (Premoli Silva et al., 1989b, 1999; Coccioni et al., 1992; Leckie et al., 2002). Such changes are in agreement with hypothesized ocean acidification for OAE 1a (Erba, 2004; Weissert and Erba, 2004; Erba et al., 2010) and OAE 2 (Kump et al., 2009; Hönish et al., 2012).

\section{Conclusions}

Quantitative study of calcareous nannofossils integrated with oxygen-isotope and $\mathrm{TEX}_{86}$ records from the Tethys and $\mathrm{Pa}-$ cific oceans has provided a reconstruction of the climatic evolution through the entire Aptian. The excellent stratigraphic time control on the studied sections coupled with high sampling density allows confirmation of some of the climatic variations detected in previous work and highlights, 
during OAE 1a, temperature fluctuations not previously detected.

The results from the Tethys and Pacific oceans confirm climatic variability through the Aptian, characterized by a warming trend that began prior to and reached a maximum during OAE 1a, coincident in time with the negative carbonisotope excursion. The rest of OAE 1a was marked by subsequent "cold snaps", and a further cooling took place when the uppermost part of the Selli Level was being deposited. A cooling marked the end of global anoxia and another longlasting cooling characterized the middle late Aptian, culminating soon after the $N$. truittii acme. The latest Aptian was, instead, characterized by a gradual warming recorded by nannofossil assemblages and TEX 86 data. SSTs from TEX 86 are suggestive of $24-27^{\circ} \mathrm{C}$ in the Tethys during OAE 1a, which is nevertheless $5-8^{\circ} \mathrm{C}$ lower than estimates from the Pacific Ocean and Boreal Realm, being probably affected by maturity levels. Although the earliest Aptian was characterized by oligotrophic conditions, the onset of OAE 1a was marked by increasing fertility, which reached a peak at a time corresponding to the core of the negative carbon-isotope excursion. A decrease in surface-water fertility is recorded from the younger part of the Selli Level. A shift to warmer and highest trophic conditions is detected after OAE 1a up to the beginning of the $N$. truittii acme interval, corresponding to minimal fertility conditions. The latest Aptian was then characterized by intermediate and fluctuating fertility, continuing into the earliest Albian.

Our data indicate that the beginning of the prolonged volcanic phase during OAE 1a coincided with the warmest temperatures associated with an increase in surface-water fertility. Weathering and hydrothermal activity were the main drivers of nutrient input, positively affecting mesotrophic taxa but having a negative impact on oligotrophic species such as nannoconids, which were not greatly affected by climatic changes. Rapid "cold snaps" are detected when OJP volcanism apparently continued, suggestive of feedback mechanisms, drawing down $\mathrm{CO}_{2}$ and affecting the climate. The end of anoxia was in phase with diminished OJP activity and global cooling. We hence see a direct relationship between OJP volcanism and climatic changes in the interval encompassing OAE 1a.

We suggest that OJP volcanism directly caused general global warming, while the excess burial of organic matter acted as an additional and/or alternative process to weathering, causing $\mathrm{CO}_{2}$ drawdown and consequent climate change during OAE 1a. Massive subaerial volcanism (Kerguelen Plateau LIP), which took place during the late Aptian, was associated with relatively cool conditions, implying the dominant effect of atmospheric $\mathrm{CO}_{2}$ drawdown via accelerated weathering.

The Supplement related to this article is available online at doi:10.5194/cp-11-383-2015-supplement.
Acknowledgements. We greatly appreciate the valuable comments by the editor, Y. Goddéris, and the reviewers, F. Giraud and A. Godet. Anchelique Mets (NIOZ) is acknowledged for assistance with the $\mathrm{TEX}_{86}$ sample preparation (NIOZ). C. Bottini, E. Erba and D. Tiraboschi were funded through MIUR-PRIN 2011. Samples from DSDP Site 463 were supplied by the Integrated Ocean Drilling Program.

Edited by: Y. Godderis

\section{References}

Ando, A., Kaiho, K., Kawahata, H., and Kakegawa, T.: Timing and magnitude of early Aptian extreme warming: Unraveling primary $\delta^{18} \mathrm{O}$ variation in indurated pelagic carbonates at Deep Sea Drilling Project Site 463, central Pacific Ocean, Palaeogeogr. Palaeocl., 260, 463-476, 2008.

Bellanca, A., Claps, M., Erba, E., Masetti, D., Neri, R., Premoli Silva, I., and Venezia, F.: Orbitally induced limestone/marlstone rhythms in the Albian-Cenomanian Cismon section (Venetian region, northern Italy): sedimentology, calcareous and siliceous plankton distribution, elemental and isotope geochemistry, Palaeogeogr. Palaeocl., 126, 227-260, 1996.

Bellanca, A., Erba, E., Neri, R., Premoli Silva, I., Sprovieri, M., Tremolada, F., and Verga, D.: Paleoceanographic significance of the Tethyan Livello Selli (Early Aptian) from the Hyblan Formation, northwestern Sicily: biostratigraphy and high-resolution chemostratigraphic records, Palaeogeogr. Palaeocl., 185, 175196, 2002.

Bernoulli, D. and Jenkyns, H. C.: Ancient oceans and continental margins of the Alpine-Mediterranean Tethys: deciphering clues from Mesozoic pelagic sediments and ophiolites, Sedimentology, 56, 149-190, 2009.

Blättler, C. L., Jenkyns, H. C., Reynard, L. M., and Handerson, G. M.: Significant increases in global weathering during Oceanic Anoxic Events 1a and 2 indicated by calcium isotopes, Earth Planet. Sc. Lett., 309, 77-88, 2011.

Bornemann, A., Pross, J., Reichelt, K., Herrle, J. O., Hemleben, C., and Mutterlose, J.: Reconstruction of short term palaeoceanographic changes during the formation of the Late Albian-Niveau Breistroffer- black shales (Oceanic Anoxic Event 1d, SE France), J. Geol. Soc. London, 162, 623-639, 2005.

Bottini, C. and Mutterlose, J.: Integrated stratigraphy of Early Aptian black shales in the Boreal Realm: calcareous nannofossil and stable isotope evidence for global and regional processes, Newsl. Stratigr., 45, 115-137, 2012.

Bottini, C., Cohen, A. S., Erba, E., Jenkyns, H. C., and Coe, A. L.: Osmium-isotope evidence for volcanism, weathering and ocean mixing during the early Aptian OAE 1a, Geology, 40, 583-586, 2012.

Bralower, T. J.: Calcareous nannofossil biostratigraphy assemblages of the Cenomanian-Turonian boundary interval: Implications for the origin and timing of oceanic anoxia, Paleoceanography, 3 , 275-316, 1988.

Bralower, T. J., Sliter, W. V., Arthur, M. A., Leckie, R. M., Allard, D. J., and Schlanger, S. O.: Dysoxic/anoxic episodes in the Aptian-Albian (Early Cretaceous), in: The Mesozoic Pacific: Geology, Tectonics and Volcanism, edited by: Pringle, M., Sager, 
W. W., Sliter, W. V., and Stein, S., American Geophysical Union, Washington, D. C., Geoph. Monog. Series, 77, 5-37, 1993.

Bralower, T. J., Arthur, M. A., Leckie, R. M., Sliter, W. V., Allard, D. J., and Schlanger, S. O.: Timing and paleoceanography of oceanic dysoxia/anoxia in the late Barremian to early Aptian, Palaios, 9, 335-369, 1994.

Bralower, T. J., Leckie, R. M., Sliter, W. V., and Thierstein, H. R.: An integrated Cretaceous microfossil biostratigraphy, in: Geochronology Time Scales and Global Stratigraphic Correlation, edited by: Berggren, W. A., Kent, D. V., Aubry, M. P., and Hardenbol, J., Geochronology, Time Scales, and Global Stratigraphic Correlation, Spec. Publ.-SEPM (Soc. Sediment. Geol.), 54, 65-79, 1995.

Bralower, T. J., Cobabe, E., Clement, B., Sliter, W. V., Osburne, C., and Longoria, J.: The record of global change in mid-Cretaceous, Barremian-Albian sections from the Sierra Madre, northeastern Mexico, J. Foramin. Res., 29, 418-437, 1999.

Channell, J. E. T., Erba, E., Muttoni, G., and Tremolada, F.: Early Cretaceous magnetic stratigraphy in the APTICORE drill core and adjacent outcrop at Cismon (Southern Alps, Italy), and the correlation to the proposed Barremian/Aptian boundary stratotype, Bull. Geol. Soc. Am., 112, 1430-1443, 2000.

Coccioni, R., Nesci, O., Tramontana, M., Wezel, C. F., and Moretti, E.: Descrizione di un livelloguida "Radiolaritico-BituminosoIttiolitico" alla base delle Marne a Fucoidi nell'Appennino Umbro-Marchigiano, Boll. Soc. Geol. Ital., 106, 183-192, 1987 (in Italian).

Coccioni, R., Franchi, R., Nesci, O., Wezel, C. F., Battistini, F., and Pallecchi, P.: Stratigraphy and mineralogy of the Selli Level (early Aptian) at the base of the Marne a Fucoidi in the UmbrianMarchean Apennines (Italy), in: Cretaceous of the Western Tethys, edited by: Wiedmann, J., 3rd International Symposium Tübingen 1987 by Schweizerbart, Stuttgart, Germany, 563-584, 1989.

Coccioni, R., Erba, E., and Premoli Silva, I.: Barremian-Aptian calcareous plankton biostratigraphy from the Gorgo a Cerbara section (Marche, Central Italy) and implication for planktonic evolution, Cretaceous Res., 13, 517-537, 1992.

De Lurio, J. L. and Frakes, L. A.: Glendonites as a paleoenvironmental tool: implications for early Cretaceous high latitude climates in Australia, Geochim. Cosmochim. Ac., 63, 1039-1048, 1999.

Dumitrescu, M. and Brassell, S. C.: Compositional and isotopic characteristics of organic matter for the early Aptian oceanic anoxic event at Shatsky Rise, ODP leg 198, Palaeogeogr. Palaeocl., 235, 168-191, 2006.

Dumitrescu, M., Brassell, S. C., Schouten, S., Hopmans, E. C., and Sinninghe Damsté, J. S.: Instability in tropical Pacific seasurface temperatures during the early Aptian, Geology, 34, 833866, 2006.

Eldholm, O. and Coffin, M. F.: Large Igneous Provinces and plate tectonics, in: The History and Dynamics of Global Plate Motion, edited by: Richards, M., Gordon, R., and van der Hilst, R., American Geophysical Union, Washington, D.C., AGU Geophysical Monograph, 121, 309-326, 2000.

Erba, E.: Aptian-Albian calcareous nannofossil biostratigraphy of the Scisti a Fucoidi cored at Piobbico (central Italy), Riv. Ital. Paleontol. S., 94, 249-284, 1988.
Erba, E.: Calcareous nannofossil distribution in pelagic rhythmic sediments (Aptian-Albian Piobbico core, central Italy), Riv. Ital. Paleontol. S., 97, 455-484, 1992a.

Erba, E.: Middle Cretaceous calcareous nannofossils from the Western Pacific (ODP Leg 129), Evidence for paleoequatorial crossing, in: Proceedings of the Ocean Drilling Program, Scientific Results, College Station, TX (Ocean Drilling Program), 129, 189-201, 1992b.

Erba, E.: Nannofossils and superplumes: the early Aptian nannoconid crisis, Paleoceanography, 9, 483-501, 1994.

Erba, E.: Calcareous nannofossils and Mesozoic oceanic anoxic events, Mar. Micropaleontol., 52, 85-106, 2004.

Erba, E.: The first 150 million years history of calcareous nannoplankton: Biosphere-geosphere interactions, Palaeogeogr. Palaeocl., 232, 237-250, 2006.

Erba, E. and Larson, R.: The Cismon Apticore (Southern Alps, Italy): Reference section for the Lower Cretaceous at low latitudes, Riv. Ital. Paleontol. S., 104, 181-192, 1998.

Erba, E. and Tremolada, F.: Nannofossil carbonate fluxes during the Early Cretaceous: phytoplankton response to nutrification episodes, atmospheric $\mathrm{CO}_{2}$ and anoxia, Paleoceanography, 19, 1-18, 2004.

Erba, E., Castradori, D., Guasti, G., and Ripepe, M.: Calcareous nannofossil and Milankovitch cycles: The example of the Albian Gault Clay Formation (southern England), Palaeogeogr Palaeocl., 93, 47-69, 1992.

Erba, E., Channell, J. E. T., Claps, M., Jones, C., Larson, R. L., Opdyke, B., Premoli Silva, I., Riva, A., Salvini, G., and Torricelli, S.: Integrated stratigraphy of the Cismon Apticore (Southern Alps, Italy): a reference section for the Barremian-Aptian interval at low latitudes, J. Foramin. Res., 29, 371-391, 1999.

Erba, E., Bottini, C., Weissert, J. H., and Keller, C. E.: Calcareous Nannoplankton Response to Surface-Water Acidification Around Oceanic Anoxic Event 1a, Science, 329, 428-432, 2010.

Erba, E., Bottini, C., Weissert, J. H., and Keller, C. E.: Response to Comment on "Calcareous Nannoplankton Response to SurfaceWater Acidification Around Oceanic Anoxic Event 1a”, Science, 332, p. 175, 2011.

Erba, E., Duncan, R. A., Bottini, C., Tiraboschi, D., Weissert, H., Jenkyns, H. C., and Malinverno, A.: Environmental Consequences of Ontong Java Plateau and Kerguelen Plateau Volcanism, GSA Special Paper, 511, doi:10.1130/2015.2511(15), 2015.

Föllmi, K. B.: Early Cretaceous life, climate and anoxia, Cretaceous Res., 35, 230-257, 2012

Föllmi, K. B. and Gainon, F.: Demise of the northern Tethyan Urgonian carbonate platform and subsequent transition towards pelagic conditions, The sedimentary record of the Col de la Plaine Morte area, central Switzerland, Sediment. Geol., 205, 142-159, 2008.

Föllmi, K. B., Godet, A., Bodin, S., and Linder, P.: Interactions between environmental change and shallow water carbonate buildup along the northern Tethyan margin and their impact on the Early Cretaceous carbon isotope record, Paleoceanography, 21, PA4211, doi:10.1029/2006PA001313, 2006.

Frakes, L. A. and Francis, J. E.: A guide to Phanerozoic cold polar climates from high-latitude ice-rafting in the Cretaceous, Nature, 333, 547-549, 1988.

Herrle, J. O.: Reconstructing nutricline dynamics of MidCretaceous oceans: Evidence from calcareous nannofossils from 
the Niveau Paquier black shale (SE France), Mar. Micropaleontol., 47, 307-321, 2003.

Herrle, J. O. and Mutterlose, J.: Calcareous nannofossils from the Aptian-Lower Albian southeast France: paleoecological and biostratigraphic implication, Cretaceous Res., 24, 1-22, 2003.

Herrle, J. O., Pross, J., Friedrich, O., Kössler, P., and Hemleben, C.: Forcing mechanisms for Mid-Cretaceous black shale formation: Evidence from the upper Aptian and lower Albian of the Vocontian Basin (SE France), Palaeogeogr. Palaeocl., 190, 399-426, 2003a.

Herrle, J. O., Pross, J., Friedrich, O., and Hemleben, C.: Shortterm environmental changes in the Cretaceous Tethyan ocean: micropalaeontological evidence from the Early Albian Oceanic Anoxic Event 1b, Terra Nova, 15, 14-19, 2003b.

Herrle, J. O., Kößler, P., Friedrich, O., Erlenkeuser, H., and Hemleben, C.: High resolution carbon isotope records of the Aptian to Lower Albian from SE France and the Mazagan Plateau (DSDP Site 545): a stratigraphic tool for paleoceanographic and paleobiologic reconstruction, Earth Planet. Sc. Lett., 218, 149-161, 2004.

Herrle, J. O., Kosler, P., and Bollmann, J.: Palaeoceanographic differences of early Late Aptian black shale events in the Vocontian Basin (SE France), Palaeogeogr. Palaeocl., 297, 367-376, 2010.

Hochuli, P. A., Menegatti, A. P., Weissert, H., Riva, A., Erba, E., and Premoli Silva, I.: Episodes of high productivity and cooling in the early Aptian Alpine Tethys, Geology, 27, 657-660, 1999.

Hong, S. K. and Lee, Y. I.: Evaluation of atmospheric carbon dioxide concentrations during the Cretaceous, Earth Planet. Sc. Lett., 327-328, 23-28, 2012.

Hopmans, E. C., Weijers, J. W. H., Schefuß, E., Herfort, L., Sinninghe Damsté, J. S., and Schouten, S.: A novel proxy for terrestrial organic matter in sediments based on branched and isoprenoid tetraether lipids, Earth Planet. Sc. Lett., 224, 107-116, 2004.

Hu, X., Kuidong, Z., Yilmaz, I. O., and Yongxiang, L.: Stratigraphic transition and palaeoenvironmental changes from the Aptian oceanic anoxic event 1a (OAE1a) to the oceanic red bed 1 (ORB1) in the Yenicesihlar section, central Turkey, Cretaceous Res., 38, 40-51, 2012.

Huber, B. T. and Leckie, R. M.: Planktic foraminiferal species turnover across deep-sea Aptian/Albian boundary sections, J. Foramin. Res., 41, 53-95, 2011.

Huguet, C., Schimmelmann, A., Thunell, R., Lourens, L. J., Sinninghe Damsté, J. S., and Schouten, S.: A study of the TEX 86 paleothermometer in the water column and sediments of the Santa Barbara Basin, California, Paleoceanography, 22, PA3203, doi:10.1029/2006PA001310, 2007.

Husinec, A., Harman, C. A., Regan, S. P., Mosher, D. A., Sweeney, R. J., and Read, J. F.: Sequence development influenced by intermittent cooling events in the Cretaceous Aptian greenhouse, Adriatic platform, Croatia, AAPG Bull., 96, 2215-2244, 2012.

Jenkyns, H. C.: Carbon-isotope stratigraphy and paleoceanographic significance of the Lower Cretaceous shallow-water carbonates of Resolution Guyot, Mid-Pacific Mountains, in: Proceedings of the Ocean Drilling Program Scientific Results, edited by: Winterer, E. L., Sager, W. W., Firth, J. V., Sinton, J. M., College Station, Texas, 143, 99-104, 1995.
Jenkyns, H. C.: Evidence for rapid climate change in the MesozoicPalaeogene greenhouse world, Philos. T. Roy. Soc. A, 361, 18851916, 2003.

Jenkyns, H. C.: Geochemistry of oceanic anoxic events, Geochem. Geophy. Geosy., 11, Q03004, doi:10.1029/2009GC002788, 2010.

Jenkyns, H. C. and Wilson, P. A.: Stratigraphy, paleoceanography, and evolution of Cretaceous Pacific guyots: relics from a greenhouse Earth, Am. J. Sci., 299, 341-392, 1999.

Jenkyns, H. C., Schouten-Huibers, L., Schouten, S., and Sinninghe Damsté, J. S.: Warm Middle Jurassic-Early Cretaceous high-latitude sea-surface temperatures from the Southern Ocean, Clim. Past, 8, 215-226, doi:10.5194/cp-8-215-2012, 2012.

Jones, C. E. and Jenkyns, H. C.: Seawater strontium isotopes, oceanic anoxic events, and seafloor hydrothermal activity in the Jurassic and Cretaceous, Am. J. Sci., 301, 112-149, 2001.

Keller, C. E., Hochuli, P. A., Weissert, H., Weissert, H., Bernasconi, S. M., Giorgioni, M., and Garcia, T. I.: A volcanically induced climate warming and floral change preceded the onset of OAE1a (Early Cretaceous), Palaeogeogr. Palaeocl., 305, 43-49, 2011.

Kemper, E.: Das Klima der Kreide-Zeit, Geologisches Jahrbuch A, 96, 5-185, 1987 (in German).

Kim, J.-H., van der Meer, J., Schouten, S., Helmke, P., Willmott, V., Sangiorgi, F., Koç, N., Hopmans, E. C., and Sinninghe Damsté, J. S.: New indices and calibrations derived from the distribution of crenarchaeal isoprenoid tetraether lipids: Implications for past sea surface temperature reconstructions, Geochim. Cosmochim. Ac., 74, 4639-4654, 2010.

Kuhnt, W., Holbourn, A., and Moullade, M.: Transient global cooling at the onset of early Aptian oceanic anoxic event (OAE) 1a, Geology, 39, 323-326, 2011.

Kuroda, J., Tanimizu, M., Hori, R. S., Suzuki, K., Ogawa, N. O., Tejada, M. L. G., Coffin, M. F., Coccioni, R., Erba, E., and Ohkouchi, N.: Lead isotopic record of Barremian-Aptian marine sediments: Implications for large igneous provinces and the Aptian climatic crisis, Earth Planet. Sc. Lett., 307, 126-134, 2011.

Kuypers, M. M. M., van Breugel, Y., Schouten, S., Erba, E., and Sinninghe Damsté, J. S.: $\mathrm{N}_{2}$-fixing cyanobacteria supplied nutrient $\mathrm{N}$ for Cretaceous oceanic anoxic events, Geology, 32, 853856, 2004.

Larson, R. L.: Geological consequences of superplumes, Geology, 19, 963-966, 1991.

Larson, R. L. and Erba, E.: Onset of the mid-Cretaceous greenhouse in the Barremian-Aptian: Igneous events and the biological, sedimentary and geochemical responses, Paleoceanography, 14, 663-678, 1999.

Leckie, R. M., Bralower, T. J., and Cashman, R.: Oceanic anoxic events and plankton evolution: Biotic response to tectonic forcing during the Mid-Cretaceous, Paleoceanography, 17, PA1041, doi:10.1029/2001PA000623, 2002.

Li, X., Jenkyns, H. C., Zhang, C., Wang, Y., Liu, L., and Cao, K.: Carbon isotope signatures changes during middle- of pedogenic carbonates from SE China: rapid atmospheric $p \mathrm{CO}_{2}$ late Early Cretaceous time, Geol. Mag., 151, 830-849, 2014.

Lopes dos Santos, R., Prange, M., Castañeda, I. S., Schefuß, E., Mulitza, S., Schulz, M., Niedermeyer, E. M., Sinninghe Damsté, J. S., and Schouten, S.: Glacial-interglacial variability in Atlantic Meridional Overturning Circulation and thermocline ad- 
justments in the tropical North Atlantic, Earth Plan. Sc. Lett., 300, 407-414, 2010.

Lorenzen, J., Kuhnt, W., Holbourn, A., Flögel, S., Moullade, M., and Tronchetti, G.: A new sediment core from the Bedoulian (Lower Aptian) stratotype at Roquefort-La Bédoule, SE France, Cretaceous Res., 39, 6-16, 2013.

Luciani, V., Cobianchi, M., and Jenkyns, H. C.: Biotic and geochemical response to anoxic events: the Aptian pelagic succession of the Gargano Promontory (southern Italy), Geol. Mag., 138, 277-298, 2001.

Mahanipour, A., Mutterlose, J., Kani, A. L., and Adabi, M. H.: Palaeoecology and biostratigraphy of early Cretaceous (Aptian) calcareous nannofossils and the $\delta^{13} \mathrm{C}_{\text {carb }}$ isotope record from NE Iran, Cretaceous Res., 32, 331-356, 2011.

Malinverno, A., Erba, E., and Herbert, T. D.: Orbital tuning as an inverse problem: Chronology of the early Aptian oceanic anoxic event 1a (Selli Level) in the Cismon APTICORE, Paleoceanography, 25, PA2203, doi:10.1029/2009PA001769, 2010.

Malinverno, A., Hildebrandt, J., Tominaga, M., and Channell, J. E. T.: M-sequence geomagnetic polarity time scale (MHTC12) that steadies global spreading rates and incorporates astrochronology constraints, J. Geophys. Res., 117, B06104, doi:10.1029/2012JB009260, 2012.

Malkoč, M., Mutterlose, J., and Pauly, S.: Timing of the Early Aptian $\delta^{13} \mathrm{C}$ excursion in the Boreal Realm, Newsl. Stratigr., 43, 251-273, 2010.

Marshall, J. D.: Climatic and oceanographic isotopic signals from the carbonate rock record and their preservation, Geol. Mag., 129, 143-160, 1992.

Maurer, F., van Buchem, F. S. P., Eberli, G. P., Pierson, B. J., Raven, M. J., Larsen, P., Al-Husseini, M. I., and Vincent, B.: Late Aptian long-lived glacio-eustatic lowstand recorded on the Arabian Plate, Terra Nova, 25, 87-94, 2012.

McAnena, A., Flögel, S., Hofmann, P., Herrle, J. O., Griesand, A., Pross, J., Talbot, H. M., Rethemeyer, J., Wallmann, K., and Wagner, T.: Atlantic cooling associated with a marine biotic crisis during the mid-Cretaceous period, Nat. Geosci., 6, 558-651, 2013.

Méhay, S., Keller, C. E., Bernasconi, S. M., Weissert, H., Erba, E., Bottini, C., and Hochuli, P. A.: A volcanic $\mathrm{CO}_{2}$ pulse triggered the Cretaceous Oceanic Anoxic Event 1a and a biocalcification crisis, Geology, 37, 819-822, 2009.

Mélières, F., Deroo, G., and Herbin, J. P.: Organic-matter-rich and hypersiliceous Aptian sediments from western Mid-Pacific Mountains, Deep Sea Drilling Project, Initial Reports, 62, 903915, 1978

Menegatti, A. P., Weissert, H., Brown, R. S., Tyson, R. V., Farrimond, P., Strasser, A., and Caron, M.: High-resolution $\delta^{13} \mathrm{C}$ stratigraphy through the early Aptian Livello Selli of the Alpine Tethys, Paleoceanography, 13, 530-545, 1998.

Millán, M. I., Weissert, H. J., Fernandez-Mendiola, P. A., and Garcia-Mondejar, J.: Impact of Early Aptian carbon cycle perturbations on evolution of a marine shelf system in the BasqueCantabrian Basin (Aralar, N Spain), Earth Planet. Sc. Lett., 287, 392-401, 2009.

Moullade, M., Kuhnt, W., Berger, J. A., Masse, J., and Tronchetti, G.: Correlation of biostratrigraphic and stable isotope events in the Aptian historical stratotype of La Bedoule (southern France),
Comptes Rendus de l'Academie des Sciences Serie II, 327, 693 698, 1998.

Mutterlose, J.: Temperature-controlled migration of calcareous nannofloras in the north-west European Aptian, in: Nannofossils and their applications, edited by: Crux, J. A. and van Heck, S. E., Ellis Horwood, Chichester, England, 122-142, 1989.

Mutterlose, J.: Migration and evolution patterns of floras and faunas in marine Early Cretaceous sediments of NW Europe, Palaeogeogr. Palaeocl., 94, 261-282, 1992.

Mutterlose, J. and Bottini, C.: Early Cretaceous chalks from the North Sea giving evidence for global change, Nature Communications, 4, 1686, doi:10.1038/ncomms2698, 2013.

Mutterlose, J., Bornemann, A., and Herrle, J. O.: Mesozoic calcareous nannofossils - state of the art, Palaeont. Z., 79, 113-133, 2005.

Mutterlose, J., Bornemann, A., and Herrle, J.: The Aptian-Albian cold snap: Evidence for "mid" Cretaceous icehouse interludes, Neues Jahrb. Geol. P.-A., 252, 217-225, 2009.

Mutterlose J., Malkoč, M., Schouten, S., Sinninghe Damsté, J. S., and Forster, A.: TEX $_{86}$ and stable $\delta^{18} \mathrm{O}$ paleothermometry of early Cretaceous sediments: Implications for belemnite ecology and palaeotemperature proxy application, Earth Planet. Sc. Lett., 298, 286-298, 2010.

Mutterlose, J., Bottini, C., Schouten, S., and Sinninghe Damsté, J. S.: High sea-surface temperatures during the early Aptian OAE 1a in the Boreal Realm, Geology, 42, 439-442, 2014.

Pauly, S., Mutterlose, J., and Wray, D. S.: Palaeoceanography of Lower Cretaceous (Barremian-Lower Aptian) black shales from northwest Germany evidenced by calcareous nannofossils and geochemistry, Cretaceous Res., 42, 28-43, 2013.

Petrizzo, M. R., Huber, B. T., Gale, A. S., Barchetta, A., and Jenkyns, H. C.: Abrupt planktic foraminiferal turnover across the Niveau Kilian at Col de Pré-Guittard (Vocontian Basin, southeast France): new criteria for defining the Aptian/Albian boundary, Newsl. Stratigr., 45, 55-74, 2012.

Peybernès, C., Giraud, F., Jaillard, E., Robert, E., Masrour, M., Aoutem, M., and Içame, N.: Stratigraphic framework and calcareous nannofossil productivity of the Essaouira-Agadir Basin (Morocco) during the Aptian-Early Albian: Comparison with the north-Tethyan margin, Cretaceous Res., 39, 149-169, 2013.

Premoli Silva, I., Ripepe, M., and Tornaghi, M. E.: Planktonic foraminiferal distribution record productivity cycles: evidence from the Aptian-Albian Piobbico core (central Italy), Terra Nova, 1, 443-448, 1989a.

Premoli Silva, I., Erba, E., and Tornaghi, M. E.: Paleoenvironmental signals and changes in surface fertility in mid-Cretaceous Corgrich pelagic facies of the Fucoid Marls (central Italy), Geobios, Mémoire Spécial, 11, 225-236, 1989b.

Premoli Silva, I., Erba, E., Salvini, G., Verga, D., and Locatelli, C.: Biotic changes in Cretaceous anoxic events, J. Foramin. Res., 29, 352-370, 1999.

Price, G. D.: The evidence and implications of polar ice during the Mesozoic, Earth-Sci. Rev., 48, 183-210, 1999.

Price, G. D.: New constraints upon isotope variation during the early Cretaceous (Barremian-Cenomanian) from the Pacific Ocean, Geol. Mag., 140, 513-522, 2003.

Price, G. D., Williamson, T., Henderson, R. A., and Gagan, M. K. Barremian-Cenomanian palaeotemperatures for Australian seas 
based on new oxygen-isotope data from belemnite rostra, Palaeogeogr. Palaeocl., 358-360, 27-39, 2012.

Roth, P. H.: Mid-Cretaceous calcareous nannoplankton from the central Pacific: implications for Paleoceanography, Deep Sea Drilling Project, Initial Reports, 62, 471-489, 1981.

Roth, P. H. and Krumbach, K. R.: Middle Cretaceous calcareous Nannofossil biogeography and preservation in the Atlantic and Indian oceans: implication for paleogeography, Mar. Micropaleontol., 10, 235-266, 1986.

Rückheim, S., Bornemann, A., and Mutterlose, J.: Planktic foraminifera from the mid-Cretaceous (Barremian-Early Albian) of the North Sea Basin: Palaeoecological and palaeoceanographic implications, Mar. Micropaleontol., 58, 83-102, 2006.

Schouten, S., Hopmans, E. C., Schefuss, E., and Sinninghe Damsté, J. S.: Distributional variations in marine crenarchaeotal membrane lipids: A new organic proxy for reconstructing ancient sea water temperatures?, Earth Planet. Sc. Lett., 204, 265-274, 2002.

Schouten, S., Hopmans, S., Forster, A., Van Breugel, Y., Kuypers, M. M. M., and Sinninghe Damsté, J. S.: Extremely high seasurface temperatures at low latitudes during the middle Cretaceous as revealed by archaeal membrane lipids, Geology, 31, 1069-1072, 2003.

Schouten, S., Hopmans, E. C., and Sinninghe Damsté, J. S.: The effect of maturity and depositional redox conditions on archaeal tetraether lipid palaeothermometry, Org. Geochem., 35, 567571, 2004.

Schouten, S., Huguet, C., Hopmans, E. C., Kienhuis, M. V. M., and Sinninghe Damsté, J. S.: Analytical methodology for TEX 86 paleothermometry by high-performance liquid chromatography/atmospheric pressure chemical ionization-mass spectrometry, Anal. Chem., 79, 2940-2944, 2007.

Sinninghe Damsté, J. S., Hopmans, E. C. Schouten, S., van Duin, A. C. T., and Geenevasen, J. A. J.: Crenarchaeol: the characteristic core glycerol dibiphytanyl glycerol tetraether membrane lipid of cosmopolitan pelagic crenarchaeota, J. Lipid Res., 43, 16411651, 2002.

Stein, M., Follmi, K. B., Westermann, S., Godet, A., Adatte, T., Matera, V., Fleitmann, D., and Berner, Z.: Progressive palaeoenvironmental change during the Late Barremian-Early Aptian as prelude to Oceanic Anoxic Event 1a: Evidence from the Gorgo a Cerbara section (Umbria-Marche basin, central Italy), Palaeogeogr. Palaeocl., 302, 396-406, 2011.

Stein, M., Westermann, S., Adatte, T., Matera, V., Fleitmann, D., Spangenberg, J. E., and Föllmi, K. B.: Late Barremian-Early Aptian palaeoenvironmental change: The Cassis-La Bédoule section, southeast France, Cretaceous Res., 37, 209-222, 2012.

Tejada, M. L. G., Katsuhiko, S., Kuroda, J., Coccioni, R., Mahoney, J. J., Ohkouchi, N., Sakamoto, T., and Tatsumi, Y.: Ontong Java Plateau eruption as a trigger for the early Aptian oceanic anoxic event, Geology, 37, 855-858, 2009.

Thiede, J., Dean, W. E., Rea, D. K., Vallier, T. L., and Adelseck, C. G.: The geologic history of the Mid-Pacific Mountains in the central North Pacific Ocean: A synthesis of Deep-Sea Drilling studies, Deep Sea Drilling Project, Initial Reports, 62, 10731120, 1981.

Thierstein, H. R. and Roth, P. H.: Stable isotopic and carbonate cyclicity in Lower Cretaceous deep-sea sediments: Dominance of diagenetic effects, Mar. Geol., 97, 1-34, 1991.
Tiraboschi, D., Erba, E., and Jenkyns, H. C.: Origin of rhythmic Albian black shales (Piobbico core, central Italy) Calcareous nannofossil quantitative and statistical analysis and paleoceanographic reconstructions, Paleoceanography, 24, PA2222, doi:10.1029/2008PA001670, 2009.

Tornaghi, M. E., Premoli Silva, I., and Ripepe, M.: Lithostratigraphy and planktonic foraminiferal biostratigraphy of the AptianAlbian "Scisti a Fucoidi" in the Piobbico core, Marche, Italy: Background for cyclostratigraphy, Riv. Ital. Paleontol. S., 95, 223-264, 1989.

Tremolada, F., Erba, E., and Bralower, T. J.: Late Barremian to Early Aptian calcareous nannofossil paleoceanography and paleoecology from the Ocean Drilling Program Hole 641C (Galicia Margin), Cretaceous Res., 87, 887-897, 2006.

van Breugel, Y., Schouten, S., Tsikos, H., Erba, E., Price, G. D., and Sinninghe Damsté, J. S.: Synchronous negative carbon isotope shifts in marine and terrestrial biomarkers at the onset of the early Aptian oceanic anoxic event 1a: Evidence for the release of ${ }^{13} \mathrm{C}$-depleted carbon into the atmosphere, Paleoceanography, 22, PA1210, doi:10.1029/2006PA001341, 2007.

Watkins, D. K.: Nannoplankton productivity fluctuations and rhythmically-bedded pelagic carbonates of the Greenhorn Limestone (Upper Cretaceous), Palaeogeogr. Palaeocl., 74, 75-86, 1989.

Weijers, J. W. H., Schouten, S., Spaargaren, O. C., and Sinninghe Damsté, J. S.: Occurrence and distribution of tetraether membrane lipids in soils: Implication for the use of the $\mathrm{TEX}_{86}$ proxy and the BIT index, Org. Geochem., 37, 1680-1693, 2006.

Weissert, H.: C-isotope stratigraphy, a monitor of palaeoenvironmental change: a case study from the Early Cretaceous, Surv. Geophys., 10, 1-61, 1989.

Weissert, H. and Erba, E.: Volcanism, $\mathrm{CO}_{2}$ and palaeoclimate: a Late Jurassic-Early Cretaceous carbon and oxygen isotope record, J. Geol. Soc. London, 161, 695-702, 2004.

Weissert, H. and Lini, A.: Ice Age interludes during the time of Cretaceous greenhouse climate?, in: Controversies in Modern Geology, edited by: Muller, D. W., McKenzie, J. A., and Weissert, H., Academic, San Diego, California, USA, 173-191, 1991.

Weissert, H., Lini, A., Föllmi, K. B., and Kuhn, O.: Correlation of Early Cretaceous carbon isotope stratigraphy and platform drowning events: A possible link?, Palaeogeogr. Palaeocl., 137, 189-203, 1998.

Williams, J. R. and Bralower, T. J.: Nannofossil assemblage, fine fraction stable isotopes, and the paleoceanography of the Valanginian-Barremian (Early Cretaceous) North Sea Basin, Paleoceanography, 10, 815-839, 1995.

Wise Jr., S. W.: Mesozoic-Cenozoic history of calcareous nannofossils in the region of the Southern Ocean, Palaeogeogr. Palaeocl., 67, 157-179, 1988.

Zakharov, Y. D., Baraboshkin, E. Y., Weissert, H., Michailova, I. A., Smyshlyaeva, O. P., and Safronov, P. P.: Late Barremian-early Aptian climate of the northern middle latitudes: Stable isotope evidence from bivalve and cephalopod molluscs of the Russian Platform, Cretaceous Res., 44, 183-201, 2013. 